\title{
Model studies of the meteorology and chemical composition of the troposphere over the North Atlantic during August 18-30, 1993
}

\author{
Frode Flatøy and Øystein Hov \\ Geophysics Institute, University of Bergen, Bergen, Norway \\ Christoph Gerbig \\ Institut für Chemıe und Dynamik der Geosphäre, Forschungszentrum Jülich, Jülich, Germany
}

\section{Samuel J. Oltmans}

NOAA Climate Monitoring and Diagnostics Laboratory, Boulder, Colorado

\begin{abstract}
A mesoscale chemistry transport model driven by meteorological data from a numerical weather prediction model is used to calculate ozone, carbon monoxide, oxides of nitrogen, and other chemical species over the North Atlantic for a 13-days period (August 18-30, 1993). The model has a circumpolar grid so that the boundary condition problems are minimized, and the influence of North American emissions on the chemical composition of the troposphere over the North Atlantic and Europe is calculated. During the first part of the period there is a zonal flow across the North Atlantic in the free troposphere; later, there is a strong north-south as well as vertical component in the advection field. The variability in the concentrations of ozone in the free troposphere is mainly caused by dynamical processes, while the chemical modification is small over an integration time of less than two weeks. A continental plume off the North American continent extending $2000 \mathrm{~km}$ or more into the North Atlantic is identified toward the end of the calculation period. There is then a maximum in the concentration of ozone around $1 \mathrm{~km}$ above the sea surface, with a much lower concentration in the marine boundary layer close to the ocean surface. Measurements from the U.K. Meteorological Office Hercules C-130 in the free troposphere off the Atlantic Provinces, across the Atlantic Ocean, and around the Azores together with ozone soundings from the Azores, Bermuda, and Iceland were used for model comparison. The calculations indicate that in the free troposphere the initial conditions as well as the upper boundary conditions are important for ozone distribution. In the upper troposphere the net change in the chemical formation rate of ozone due to a change in the $\mathrm{NO}_{x}$ concentration is quite independent of the absolute value of the ozone concentration itself and, consequently, the choice of boundary conditions for ozone is not so important in this context. In the lower troposphere the change in the net chemical formation rate of ozone, which follows from a change in the concentration of $\mathrm{NO}_{x}$, shows a marked dependence on the concentration of ozone.
\end{abstract}

\section{Introduction}

Surface ozone has been measured onboard various research vessels in the Atlantic Ocean over the last 15 years [Winkler, $1988,1989]$. On average the ozone concentration in the boundary layer over the North Atlantic is about twice the southern hemisphere concentration, with a minimum in the Intertropical Convergence Zone (ITCZ). The annual average ozone concentration in the $25^{\circ}-65^{\circ} \mathrm{N}$ latitude belt, which is of particular relevance for Europe, is about $30 \mathrm{ppb}$. There is a spring maximum in the northern hemisphere with a peak in May [Winkler, 1989] and a minimum during fall or winter. The spring peak increases in intensity going northward from the ITCZ to $40^{\circ}-50^{\circ} \mathrm{N}$.

Copyright 1996 by the American Geophysical Union.

Paper number 96JD01227.

0148-0227/96/96JD-01227\$09.00
Meridional cross sections of tropospheric ozone in the Atlantic have been recorded several times based on ozonesonde measurements from research vessels and aircraft measurements. Smit et al. [1989, 1990] carried out ozonesonde measurements during two ship cruises. During the spring cruise in 1987 between $37^{\circ} \mathrm{S}$ and $46^{\circ} \mathrm{N}$ there were low ozone values near the surface in the southern hemisphere and a large vertical gradient. The lowest ozone concentration was measured at $10^{\circ} \mathrm{S}(8 \mathrm{ppb})$. In the northem hemisphere, large mixing ratios up to $55 \mathrm{ppb}$ were found near the surface, and with a weak vertical gradient. Around $30^{\circ} \mathrm{N}$ it was found that stratosphere-troposphere exchange strongly influenced the tropospheric ozone values. In the autumn cruise of 1988 , between $30^{\circ} \mathrm{S}$ and $52^{\circ} \mathrm{N}$, low ozone was found in the tropical region from $5^{\circ} \mathrm{N}$ to $15^{\circ} \mathrm{N}$ extending from the ground to the tropopause. Results from instrumented flights in 1983 confirm that the ozone content in the northern hemisphere over the Atlantic (50-60 $\mathrm{ppb}$ ) is about twice that in the southern hemisphere (25-30 ppb) [Marenco, 1988; Marenco and Said, 1989]. 
In the northern hemisphere the major part of the anthropogenic $\mathrm{NO}_{x}$ and $\mathrm{SO}_{2}$ emissions are found in North America, Eurasia, and the far East. To estimate the eastward transport of acid compounds from anthropogenic emissions in North America to the Atlantic Ocean, Brost et al. [1988] used an Eulerian mesoscale chemical transport model, described by Chang et al. [1987] for the meteorological conditions of April 1982, and found that in a layer from the surface to $5.5 \mathrm{~km}$ the eastward atmospheric flux over the Atlantic Ocean of sulphur was $4.8 \mathrm{MtS} / \mathrm{yr}$ and of nitrogen 1.8 $\mathrm{MtN} / \mathrm{yr}$, while the total North American anthropogenic source of $\mathrm{SO}_{2}$ was $15 \mathrm{MtS} / \mathrm{yr}$ and of $\mathrm{NO}_{x} 7.9 \mathrm{MtN} / \mathrm{yr}$ in 1982. This means that the major part of the $\mathrm{SO}_{2}$ (about $70 \%$ ) and $\mathrm{NO}_{x}$ (about 75\%) emissions were deposited over North America, but the remaining 25-30\% were transported mainly eastward over the North Atlantic or vented to the free troposphere. Together with the emissions of nonmethane hydrocarbons there is a significant potential for photooxidant formation, in particular in the summer months. The calculated S flux and the speciation was in broad agreement with the estimates based on measurements by Galloway et al. [1984]. For nitrogen, the agreement of the calculated flux with measurements was more uncertain [Brost et al., 1988]. The eastward transport of pollutants from North America takes place in events determined by the meteorological conditions. The chemical composition of the troposphere over the North Atlantic is therefore quite variable depending on both the synoptic situation and the time of the year.

The North Atlantic Region Experiment (NARE) intensive during August 1993 also included the participation of european scientists involved in the OCTA (Oxidizing Capacity of the Tropospheric Atmosphere) project funded by the European Union. In the time period August 19 to September 1, 1993, the U.K. Meteorological Office Hercules C-130 aircraft carried out measurements of ozone, $\mathrm{NO}, \mathrm{NO}_{y}$ (the sum of $\mathrm{NO}$ and $\mathrm{NO}_{2}$, together called $\mathrm{NO}_{x}, \mathrm{HNO}_{2}, \mathrm{NO}_{3}, \mathrm{~N}_{2} \mathrm{O}_{5}, \mathrm{HO}_{2} \mathrm{NO}_{2}, \mathrm{HNO}_{3}$, nitrate aerosol, PAN, and other organic nitrates), hydrogen peroxide, individual

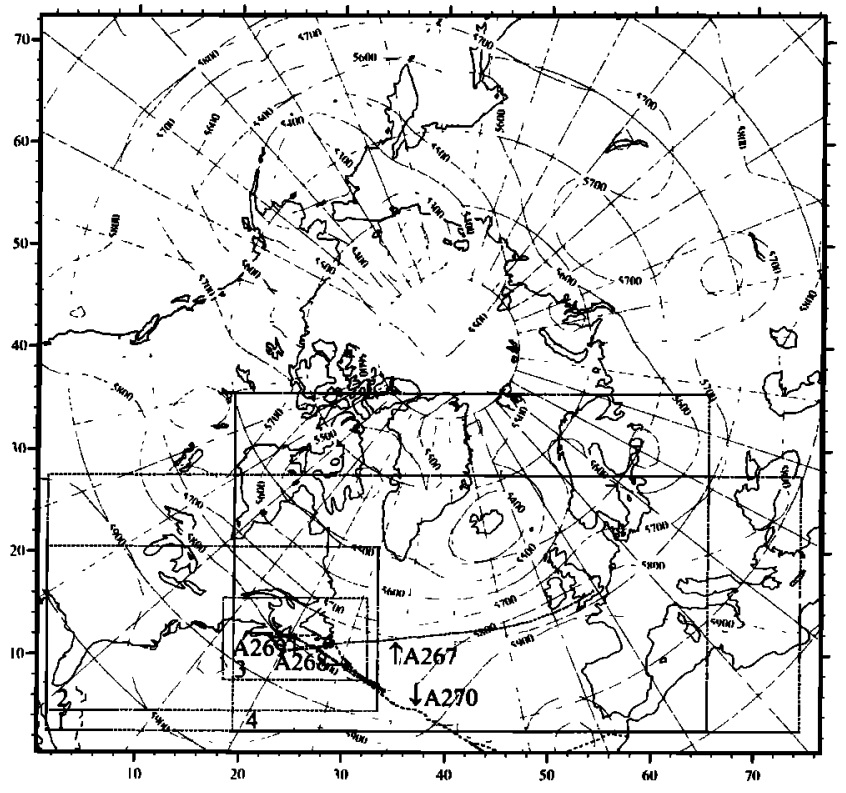

Figure 1. European Centre for Medium-Range Weather Forecasts (ECMWF) analysis of the $500-\mathrm{hPa}$ surface height at $1200 \mathrm{UT}$, August 19, 1993. The total $(72 \times 76)$ model domain is shown as well as subareas used in the paper. The horizontal tracks of Oxidizing Capacity of the Tropospheric Atmosphere (OCTA) flights A267, A268, A269, and A270 are indicated. hydrocarbons, carbon monoxide and meteorological parameters on a number of flights from Farnborough in the United Kingdom to Halifax (flight A267), from Halifax to St. Johns (flight A268), St. Johns roundtrip (flight $A 269$ ), and then across the Atlantic via the Azores to Rabat (flight A270).

The purpose of this paper is to present the results of threedimensional Eulerian model calculations of the chemical composition of the troposphere over the North Atlantic during the NARE intensive and to use some of the aircraft measurements from the OCTA flights in August 1993 for model validation.The following questions are discussed in this paper based on the model calculations:

1. In the free troposphere over the North Atlantic, what are the relative roles of physical redistribution of ozone and photochemical generation (or loss) in situations with a predominant zonal flow?

2. How long does it take for continental plumes of ozone and precursors off the North American continent to become dispersed and difficult to distinguish from northern hemisphere midlatitude "background" concentrations?

3. How significant is the choice of initial and upper boundary conditions for species like ozone for the calculated free tropospheric chemical composition?

4. To what extent is the net change in the chemical formation rate of free tropospheric ozone which follows from a change in the concentration of $\mathrm{NO}_{x}$, dependent on the concentration of ozone itself?

\section{Model Description}

The general approach used in the model is similar to that used in several other three-dimensional models developed in the past decade [Liu et al., 1984; Chang et al., 1987; Carmichael et al., 1991; McKeen et al., 1991; Hass et al., 1993]. The mesoscale chemical transport (MCT) model is closely coupled to a numerical weather prediction (NWP) model with an advanced treatment of cloud physics and precipitation processes. This allows a detailed parameterization of convective transport and the calculation of photolysis rates in cloudy conditions to be made. A circumpolar grid is applied (Figure 1) and the study covers a 13-day period (August 18-30, 1993). The large circumpolar grid is chosen for the calculations to ensure that most of the conversion of anthropogenic and natural emissions of $\mathrm{NO}_{x}$, volatile organic compounds (VOC) and other species over North America, Europe, and Asia take place within the model volume. In this way it is attempted to minimize the effect of not well-known upwind boundary conditions, and since the advection field has a predominant westerly component, the air masses will remain inside the model domain for a substantial part of the integration period. This is further discussed by Flatøy and Hov [1996b].

The NWP model is based on the limited area model NORLAM from the Norwegian Meteorological Institute, described by Gronås et al. [1987], Nordeng [1986], and Kvamstø [1992]. Sigma coordinate primitive equations which are integrated on a stereographic map projection are used. The horizontal domain and the size of the grid elements are indicated in Figure 1 and are the same in the NWP and MCT models. In subsequent figures, only sections of the domain are presented. Meteorological fields from the NWP model are in the present setup stored once every hour. The horizontal grid resolution of the input and the results is 150 $\mathrm{km}$ at $60^{\circ} \mathrm{N}$ and there are 10 unequally spaced vertical layers extending up to $100 \mathrm{hPa}$. With this rather coarse resolution no interpolation in time of the meteorological data is thought neces- 
sary before use by the MCT model. The NWP model also supplies data for land use, topography, vegetation and ground albedo. Analysis every 6 hours from the European Centre for MediumRange Weather Forecasts (ECMWF) are used as initial and boundary conditions for a set of 18-hour prognosis with the NWP model. The first 6 hours of each prognosis are considered as spinup and are skipped, while the following 12 hours are used. The meteorological input to the MCT model then consists of a chain of independent 12-hour prognosis segments.

The transport part of the MCT model is described by Flatoy et al. [1995] and Flatøy [1993] and the chemistry part by Flatøy and Hov [1996a]. The chemistry scheme includes more than 40 chemical species and more than 120 chemical reactions for the gas phase formation of photooxidants. The emissions of volatile organic compounds (VOC) are represented by six non methane hydrocarbons (NMHC) and several oxygenated VOCs, in addition to isoprene. Nighttime chemistry is assumed to occur through nitrate radical attack on VOCs. Both peroxy radical pluss NO and peroxy radical pluss peroxy radical reactions are included to assure validity of the reaction scheme over a wide range of NO concentrations. Aerosol and liquid phase chemistry is parameterized. The chemistry scheme is documented by Strand and Hov [1994], who applied it in a study of global ozone. Figure 2 shows the initial values for some of the key species employed in the simulation. The rest of the components are given concentrations which are consistent with the concentrations of the species shown in Figure 2. The initial values are also used as boundary conditions.

The most recent EMEP (Co-operative Program for Monitoring and Evaluation of the Long Range Transmission of Air Pollutants in Europe) emissions' inventory for 1991 is utilized, adopted from Sandnes [1993] for $\mathrm{NO}_{r}$ and $\mathrm{SO}_{2}$ emissions and from Simpson [1992] for anthropogenic NMHC emissions. The natural VOC emissions represented by isoprene are derived by an emissiontemperature relationship from Lubkert and Schöpp [1989] using the forest cover and the variable surface temperature from the result of the NWP model calculations. The formula gives low isoprene emissions at night, following the diurnal cycle in the surface temperature. The temperature is here also a surrogate for the effect

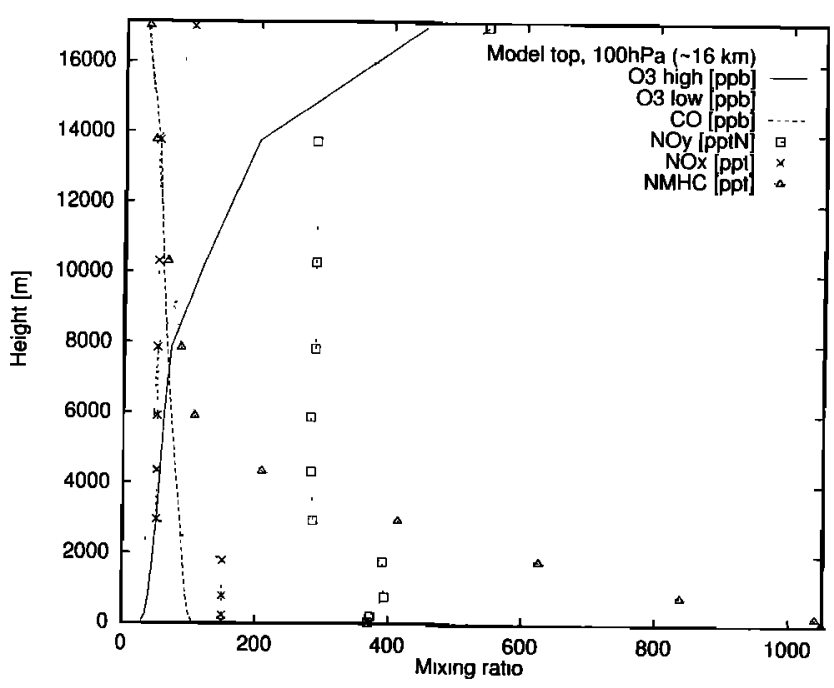

Figure 2. Initial and boundary concentrations of some of the key species. Values above the model top are applied as upper boundary conditions. of the variation in the photosynthetically active radiation (PAR), which strongly affects the isoprene emissions. Empirical relationships for the dependence of the isoprene emissions on both temperature and PAR have been reported in the literature [Guenther et al., 1993]. Aircraft $\mathrm{NO}_{x}$ emissions are taken from the Abatement of Nuisances Caused by Air Transport/European Civil Aviation Conference $(A N C A T / E C A C)$ [1995] and the lightning $\mathrm{NO}_{x}$ emissions are from Köhler et al. [1995].

The surface emissions of $\mathrm{NO}_{x}, \mathrm{SO}_{2}$, and VOC inside the model domain are specified for North America, Europe, and Russia west of the Ural Mountains, and the rest of Russia and Asia are shown in Table 1 as annual average figures. Also shown are the emissions from aircraft and lightning. The surface sources of $\mathrm{NO}_{x}, \mathrm{SO}_{2}$, and VOC are given annual variations as specified in the table; for VOC the emissions are constant over the year but have been given a diurnal profile where the emissions are 0.5 times the diurnal mean between 1800 and $0600 \mathrm{LT}$ and 1.5 times the diurnal mean between 0600 and 1800 LT.

The $\mathrm{NO}_{x}$ emissions outside of the EMEP model domain (which covers Europe and Russia west of the Ural) are taken from Benkovitz et al. [this issue]. For North America and Asia/Russia the anthropogenic VOC emissions are set equal to the $\mathrm{NO}_{x}$ emissions by mass $\left(\mathrm{NO}_{x}\right.$ as $\left.\mathrm{NO}_{2}\right)$ and are given the same spatial distribution as $\mathrm{NO}_{x}$ but without annual variation. This is probably a reasonable approximation; the National Acid Precipitation Assessment Program (NAPAP) inventory for the eastern United States indicates a ratio of about 1.1 between the emissions of $\mathrm{VOC}$ and $\mathrm{NO}_{\lambda}$ when $\mathrm{NO}_{x}$ is measured as $\mathrm{NO}_{2}$, as a diurnal average for a summertime weekday [McKeen et al., 1991]. In the NAPAP inventory the average CO emission for eastern North America for 1985 is $382 \mathrm{ng} / \mathrm{m}^{2}$ $\mathrm{s}$ for $\mathrm{CO}$ and $158 \mathrm{ng} / \mathrm{m}^{2} \mathrm{~s}$ for VOC, so that the ratio between the $\mathrm{CO}$ and the VOC emissions is about 2.4 by mass. In the global emission inventory compiled by Hough [1991], a ratio of 8.5 by mass was found for the emission of $\mathrm{CO}$ relative to $\mathrm{NMHC}$ for man-made sources ("industrialized society"). In the calculations presented here, the ratio is taken to be 3.5 for the whole model domain.

\section{Synoptic Situation}

In the beginning of the simulation period August 18-30, 1993 there was a well-defined polar front over the North Atlantic region with a low-pressure center over Iceland and zonal flow. Later, the zonal flow was interrupted by a strong low-pressure system south of Greenland and a weaker one over Spain. This can be seen in Figures 1 and 3 which show the analysis of the 500-hPa surface height at 1200 UT August 19, 1993, and 1200 UT August 26, 1993. The interruption of the frontal zone during August 19-26 is even more evident if we look at the $500-\mathrm{hPa}$ potential temperature shown in Figure 4. On August 19 the isentropic surfaces intersected the $500-\mathrm{hPa}$ surfaces along almost zonal lines across the North Atlantic with warm air to the south and cold air to the north. One week later, rising tongues of warm air penetrate the $500-\mathrm{hPa}$ surface between Greenland and Iceland on the leading edge of a cyclone system (Figure 3), while descending colder air moved southward on the back side of the cyclone. Over the eastern provinces of the United States and Canada, descending cold air moved southward on the back side of a trough there and ascending warm air moved northward between Newfoundland and Greenland. The zonal flow on August 19 was therefore replaced by advection with a strong vertical as well as meridional component in the North Atlantic on August 26. Based on two-dimensional trajectories for 
Table 1. Emissions Employed in Simulations

\begin{tabular}{lccccc}
\hline & $\begin{array}{c}\mathrm{SO}_{2}, \\
\mathrm{Mt} \mathrm{SO}_{2} / \mathrm{yr}\end{array}$ & $\begin{array}{c}\mathrm{NO}_{x}, \\
\mathrm{Mt} \mathrm{NO}_{2} / \mathrm{yr}\end{array}$ & $\begin{array}{c}\text { VOC, } \\
\mathrm{Mt} \mathrm{VOC} / \mathrm{yr}\end{array}$ & $\begin{array}{c}\text { Air Traffic, } \\
\mathrm{Mt} \mathrm{NO}_{2} / \mathrm{yr}\end{array}$ & $\begin{array}{c}\text { Lightning, } \\
\mathrm{Mt} \mathrm{NO}_{2} / \mathrm{yr}\end{array}$ \\
\hline Global & 130.11 & 68.85 & 72.36 & 2.74 & 15.57 \\
Model domain (Figure 1) & 86.61 & 48.18 & 51.68 & 1.84 & 3.23 \\
North America (inside domain) & 23.63 & 17.93 & 17.93 & 0.73 & 0.51 \\
Europe/Russia (EMEP domain) & 40.66 & 22.87 & 26.38 & 0.85 & 0.36 \\
Asia/Russia (inside domain) & 22.11 & 7.25 & 7.25 & 0.18 & 2.18 \\
Fraction of global emissions inside model domain & $67 \%$ & $70 \%$ & $71 \%$ & $67 \%$ & $16 \%$ \\
\hline
\end{tabular}

The $\mathrm{NO}_{\mathrm{r}}$ and $\mathrm{SO}_{2}$ emissions are given an annual variation $(1+0.33 \cos (($ month- 1$)+$ date/30 $) \pi / 6)=0.779$. The VOC emissions are constant over the year with a diurnal variation ( 0.5 between 1800 and 0600 LT and 1.5 between 0600 and 1800 LT).

the 500-hPa layer, we find that the transport time across the Atlantic has increased from $\sim 36$ to $\sim 92$ hours for trajectories arriving in Europe August 19 and 26, respectively. The August 26 trajectories are significantly influenced by vertical motions and the transport time estimated from the isobaric trajectories should therefore be considered as an indication only.

The change in the flow field has a large influence on the transport of tracers. One such tracer is specific humidity. Figure 5 shows the 500-hPa specific humidity for August 19 and August 26. The specific humidity is low in regions with descending air and high in ascending air masses from the lower troposphere. In Figure 5 on August 26, low specific humidity coincides with cold, descending air masses moving southward and high specific humidity with warmer, ascending air masses moving northward on the leading edge of the low-pressure centers. The distribution of specific humidity in the 500-hPa surface shown in Figure 5 supports the interpretation of the flow in the midtroposphere over the North Atlantic on August 19 and 26 based on the height of the $500-\mathrm{hPa}$ surface (Figures 1 and 3 ) and the potential temperature contours on the 500-hPa surface shown in Figure 4.

\section{Ozone in the Free Troposphere Over the North Atlantic}

Figure 6 shows the computed ozone concentration [ppbv] at 1200 UT August 19, 1993, and 1200 UT August 26, 1993. When compared with Figure 5, ozone is low when the specific humidity is high, indicating transport from below through the $500-\mathrm{hPa}$ surface, while ozone is high when the specific humidity is low in descending air of upper tropospheric origin. The inverse relationship between the spatial distribution of ozone and the specific humidity in the middle free troposphere indicates that the influence from the chemistry in the redistribution and absolute levels of ozone is low compared to the dynamical forcing from the meteorology. This was further demonstrated by Flatoy and Hov [1996a], who found that on the average for ozone in the upper troposphere during summer the magnitude of the chemistry term in the continuity equation for the local rate of change in the concentration with time was less then $1 \%$ of the transport term. This means that the spatial variability in ozone in the middle and upper troposphere on a day-to-day basis is largely determined by dynamical processes.

A significant fraction of the concentration of $\mathrm{O}_{3}$ in the middle and upper troposphere is generated chemically in the troposphere, however, but this is a rather slow process (it takes typically 100 days before the full effect on ozone is seen of the current concen- tration levels of free tropospheric methane, carbon monoxide, and oxides of nitrogen). On a specific day at most 5-10 ppb of $\mathrm{O}_{3}$ can be generated in the free troposphere over continental regions where there can be substantial $\mathrm{NO}_{x}$ emissions and when there is convective activity, but usually only a few parts per billion or less of $\mathrm{O}_{3}$ are generated or lost in a single day in a given location in the free troposphere through chemical processes [Flatøy and Hov, 1996a].

In a model calculation where the chemical term in the continuity equation for ozone was deleted, the concentration distribution for $\mathrm{O}_{3}$ at the $500-\mathrm{hPa}$ level was similar to what is seen in Figure 6 but a few parts per billion lower in magnitude over the North Atlantic. This confirms that integrated over a 2-week period only, the absolute level and variability in the concentration of ozone in the free troposphere is to a large extent determined by the boundary and initial conditions and the advection field, while chemical processes may add or subtract a few percent of the total concentration. The control exerted by dynamical processes of the concentration of ozone is seen also in Figure 7 where calculated data are compared with ozone sonde measurements at the Azores, Bermuda, and Iceland of ozone, potential temperature, and relative humidity during the simulation period for the troposphere and up to about $13 \mathrm{~km}$. The calculated and measured values compare reasonably well for most days, but the coarse resolution of the model means that details in the measured vertical profiles of ozone and relative humidity cannot be resolved (the approximate height

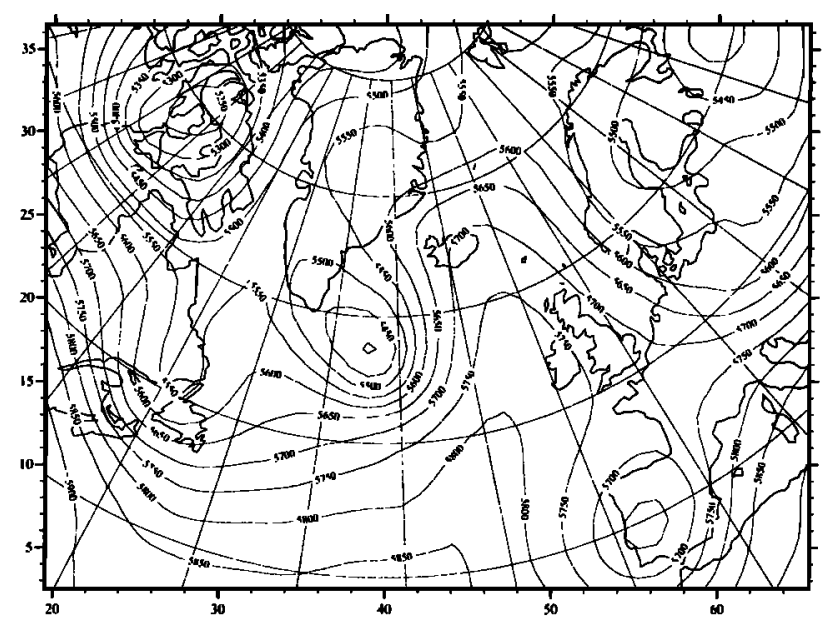

Figure 3. ECMWF analysis of the $500-\mathrm{hPa}$ surface height at 1200 UT, August 26, 1993. 

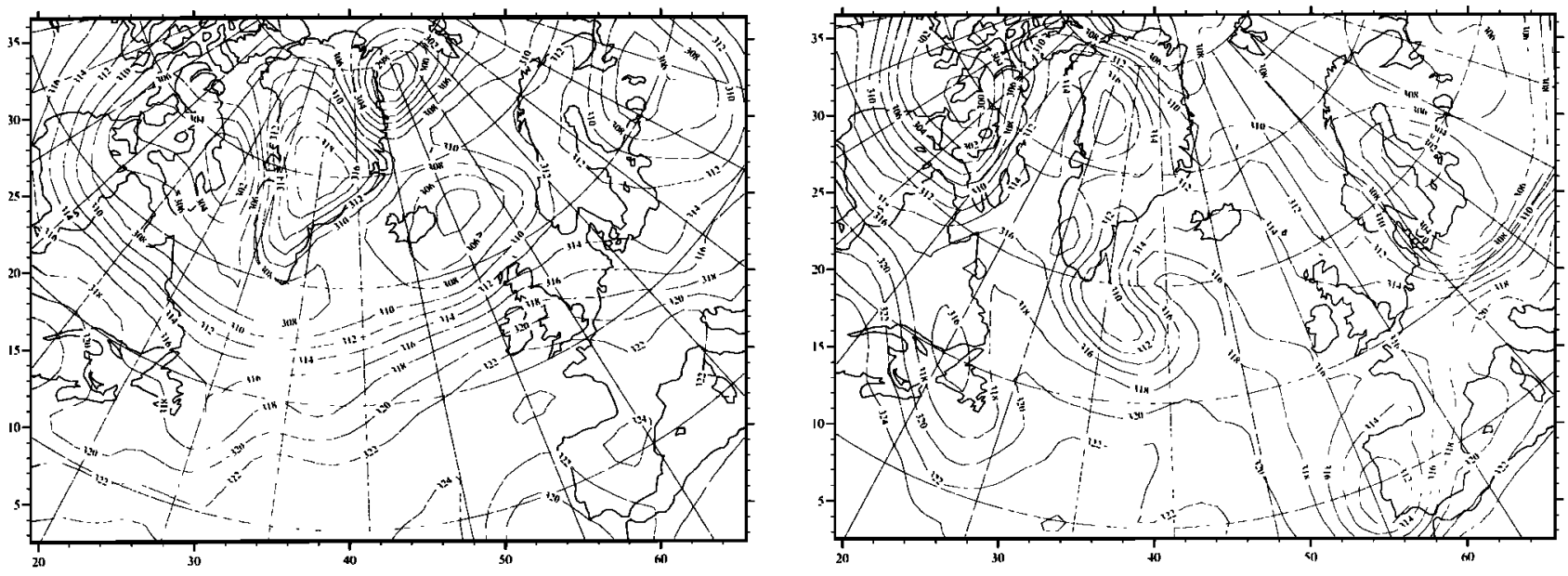

Figure 4. Norwegian Limited Area Model (NORLAM) 500-hPa potential temperature at 1200 UT, August 19 and 1200 UT, August 26, 1993 (NORLAM is the numerical weather prediction model originating at the Norwegian Meteorological Institute).

above the ground of the midlevel of each model layer is indicated in Figure 2). It should also be kept in mind that at the start of the simulation the initial concentration profiles (Figure 2) are applied throughout the model domain regardless of the local height of the tropopause. The calculated distributions of physical and chemical parameters have had a limited time to develop details and are affected by the choice of initial conditions.

At the northernmost site Keflavik on Iceland the tropopause height, as judged by the change in slope with height in ozone, potential temperature, and relative humidity, is lower than at the Azores or Bermuda. The calculated profiles of ozone, potential temperature, and relative humidity reproduce well the change in tropopause height with latitude. The upper boundary condition for ozone used in the model (Figure 2) is constant with time and throughout the model domain and equal to 150 parts per billion. This is a mixing ratio which is representative of the tropopause region. In the southern part of the model domain the height of the upper boundary (about $15 \mathrm{~km}$ ) coincides with the tropopause region and the upper boundary condition for ozone of 150 parts per billion is appropriate (see Figure 7), while in the northern part of the domain, the tropopause height is lower and the upper part of the model domain is located in the stratosphere where the ozone mixing ratio increases rapidly with height, as can be seen in the ozone sonde profiles from Keflavik, Iceland, in Figure 7. The ozone concentration in the upper two layers of the model is not realistic at high latitudes, and in any cases, the effect on upper tropospheric ozone of a low tropopause or the formation of tropopause folds is not properly accounted for in the present version of the model. A realistic simulation of ozone flow across the tropopause can be obtained by redefining the upper boundary condition for ozone and increasing the height of the upper boundary in the model. The comparison of the calculated and measured vertical profiles in Figure 7 indicates that the model results for potential temperature (Figure 4), specific humidity (Figure 5), and ozone (Figure 6) in the 500-hPa surface present a realistic approximation to the actual situation.

\section{NARE/OCTA Measurements}

Field measurements together with model interpretation are required to explain the continuously changing chemical composition of the atmosphere. The MCT model has a coarse resolution
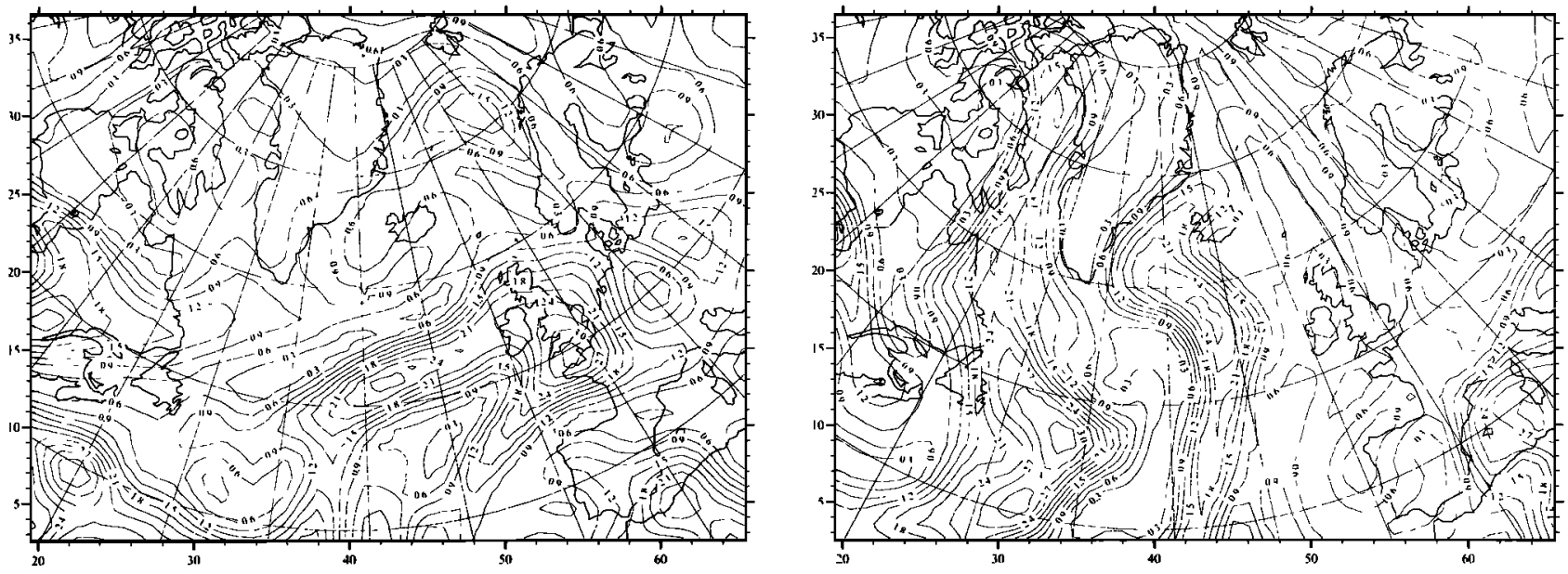

Figure 5. NORLAM 500-hPa specific humidity (grams per kilogram) at 1200 UT, August 19 and 1200 UT, August $26,1993$. 

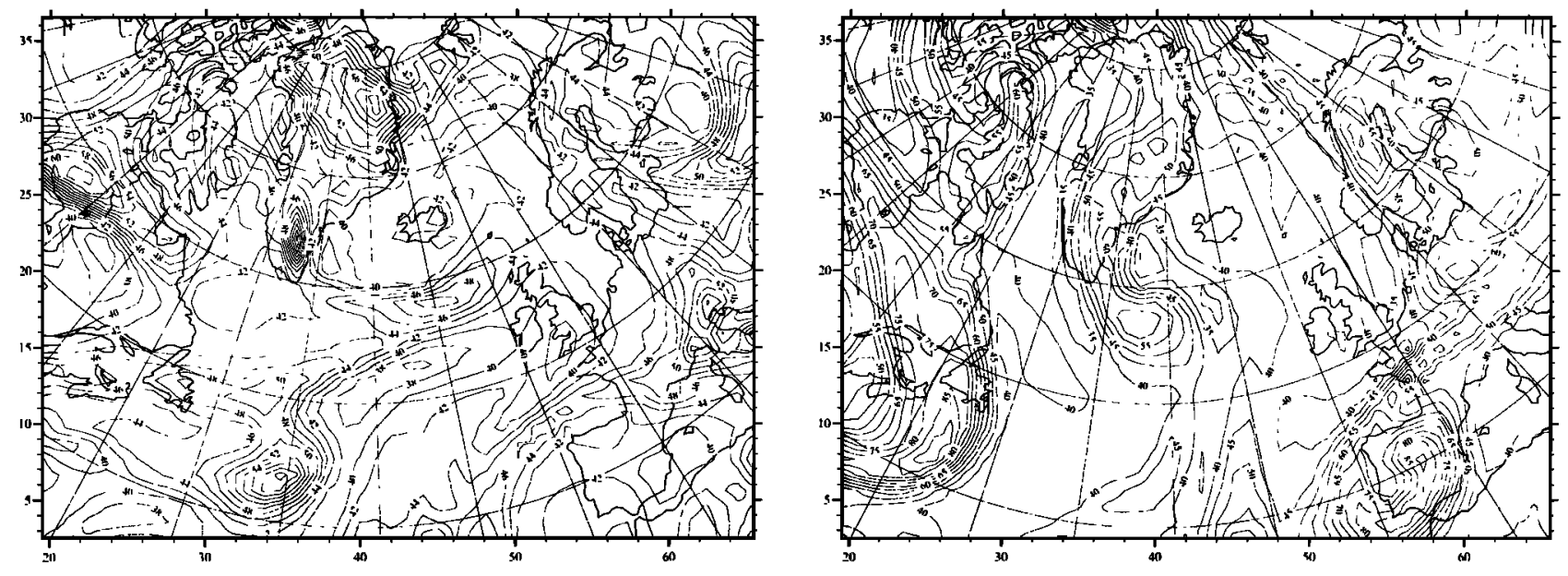

Figure 6. Modeled 500-hPa ozone concentration (parts per billion by volume) at 1200 UT, August 19 and 1200 UT, August 26, 1993.

and its prediction skill is dependent on the available knowledge of the initial composition and the upper boundary conditions, which in most cases is sparse. The model gives the chemical composition of the troposphere as a function of space and in time resulting from the solution of the continuity equation for each chemical compound subject to assumptions about emissions, reaction rate coefficients, physical removal processes, dispersion, and initial and boundary conditions. Measurements can provide the local chemical concentration of a few key species but do not provide a direct explanation of how the composition arose. The measurements can be used to assess the model's prediction capabilities, and the model can then provide information about the chemical and meteorological processes that gave rise to the observed concentrations.

Figure 1 shows the horizontal trace of the flight tracks of the OCTA/NARE flights A267 from Farnborough, United Kingdom, to Halifax, A268 from Halifax to St. Johns, Newfoundland, A269 from St. Johns to Nova Scotia and back, and A270 from St. Johns to Rabat, Morocco. Figure 8 shows the corresponding flight altitudes as a function of time, together with the modeled ozone in a vertical column along the flight trajectories. It should be noted that flights A267 and A270 crossed the Atlantic, while the two intermediate flights took place on two consecutive days over the Atlantic provinces and Newfoundland, included several ascents and descents, and the horizontal trace of the flight path was quite curved (Figure 1).

In Figures 9 to 12, model results are compared with measured values of $\mathrm{O}_{3}, \mathrm{CO}, \mathrm{NO}$, and $\mathrm{NO}_{y} \mathrm{CO}$ was measured using the resonance fluorescence detector described by Gerbig et al. [this issue]. For flight A269 there are no CO measurements due to an instrument malfunction. $\mathrm{NO}$ and $\mathrm{NO}_{y}$, i.e., the sum of $\mathrm{NO}_{x}$ and its oxidation products, were measured with a chemiluminescence instrument, the latter using a gold converter [Fahey et al., 1985] to convert the different $\mathrm{NO}_{y}$ species to NO. The instrument is described by Lerner et al. [1994] and further in Gerbig et al. [this issue]. For $\mathrm{CO}$ and $\mathrm{NO}_{2}, 16-\mathrm{s}$ running means are shown and for NO 3-min averages are shown. The resulting errors are about 3 $\mathrm{ppb}$ for $\mathrm{CO}, 20 \mathrm{ppt}$ for $\mathrm{NO}_{\mathrm{y}}$, and $8 \mathrm{ppt}$ for NO. The calculated concentration of ozone compared reasonably well with the vertical soundings shown in Figure 7. The same is seen for flights A269 and A270 and, to some extent, also for flight A267. The systematic difference between modeled and measured concentrations during flight A268 seems to be caused by weak subsidence, so that more ozone, influenced by the upper boundary condition, was brought downward than calculated by the model. As stated above, advection is the most important factor in the redistribution of free tropospheric ozone on the timescale of the order of 1 day, and the calculated distribution of free tropospheric ozone is therefore quite dependent on the initial and boundary conditions. If these conditions are well chosen, a good agreement is to be expected between the measured and the calculated concentration distributions, and the differences are often largest when the stratospheric influence, which is not quantified well, is large. We consider flight A269 to be the most interesting one since the changes calculated in the ozone concentration distribution compared to the initial conditions, are quite large, and these changes are reproduced by the model. During the flight the model computes increased ozone around $3000 \mathrm{~m}$ and lower concentrations around $5000 \mathrm{~m}$ (Figure 8 , panel 3 ), this is also seen from the measurements (Figure 11) and is particularly notable between 211 and 212 hours since the start of the integration on August 18.

Flight A269 took place on August 26, which corresponds to the date of the $500-\mathrm{hPa}$ distributions of potential temperature, specific humidity, and ozone shown in Figures 4-6 (bottom panels). The advection of cold, dry, and ozone rich air downward toward the southeast over the Atlantic Provinces and Newfoundland can be seen clearly, and this type of air is calculated to penetrate down into the lower troposphere (panel 3 in Figure 8), in particular for 206-207 hours.

The measured $\mathrm{CO}$ concentrations are on the average $20 \%$ higher than the calculated ones. The anthropogenic $\mathrm{CO}$ emissions from North America used in the model (see section 2) are higher than in the NAPAP inventory (about $50 \%$ higher), according to Thompson et al. [1994] the source term in the continuity equation for CO can still be underestimated. Pierson et al. [1990] and Buhr et al. [1992] have suggested that the $\mathrm{CO}$ emissions are underestimated in the NAPAP inventory, and model simulations by Jacob et al. [1993] with the NAPAP mobile source CO emissions doubled compare better with $\mathrm{CO}$ observations at some stations and worse at others. The initial and boundary condition for $\mathrm{CO}$ is 100 ppb close to the ground and falling off to $50 \mathrm{ppb}$ at the upper boundary (see Figure 2); this is an underestimate over the continents and could contribute to a lower calculated than measured concentration of $\mathrm{CO}$ in particular in the beginning of the model 

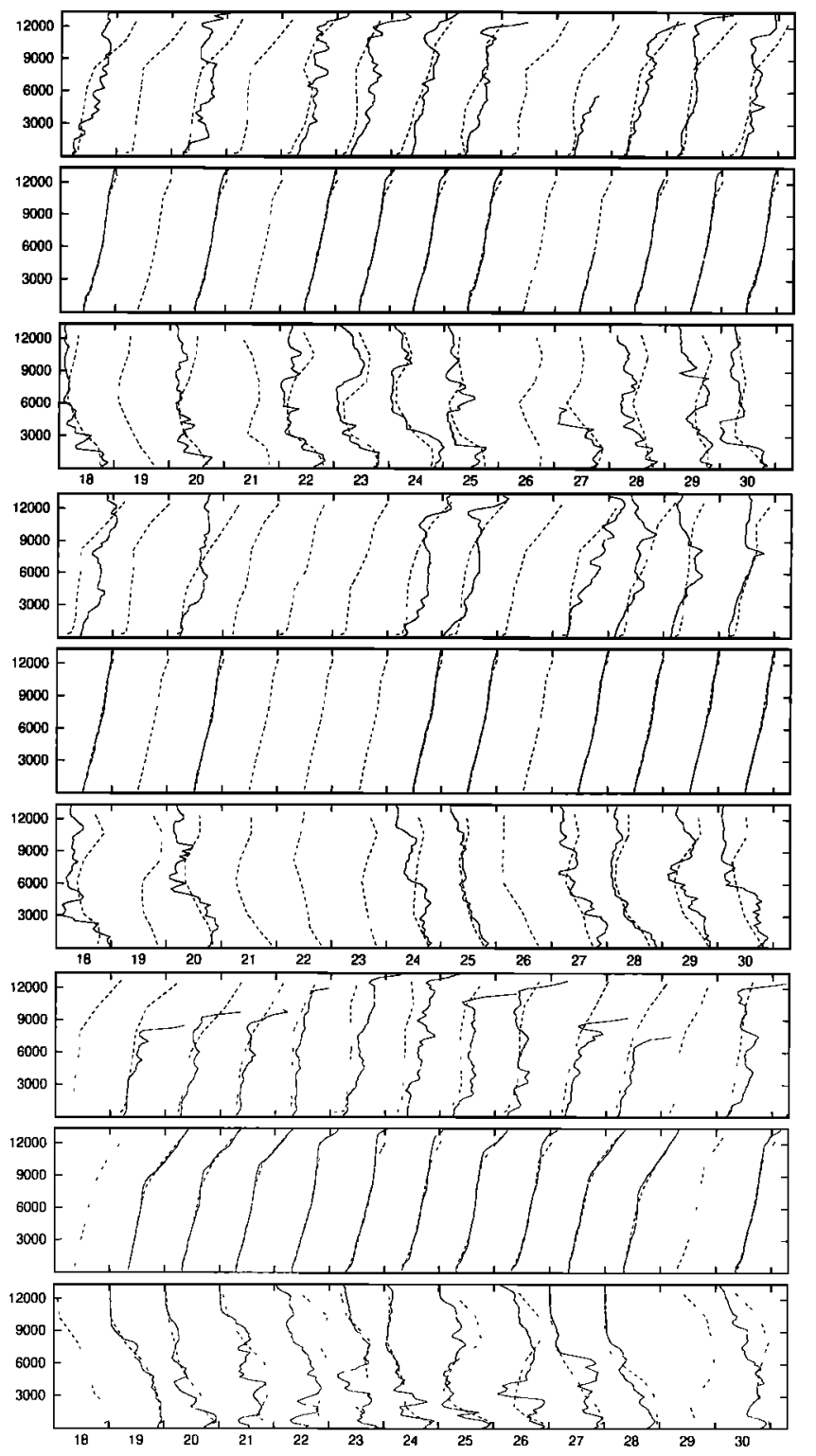

Figure 7. Measured (solid lines) and modeled (dashed lines) vertical profiles of $\mathrm{O}_{3}$ (parts per billion by volume), potential temperature (K), and relative humidity at the Azores (panels 1-3), Bermuda (panels 4-6) and Iceland (panels 7-9) during August 18 to 30,1993 . Range between tick marks: $0-100 \mathrm{ppb}, 250-350 \mathrm{~K}$, and $0-100 \%$.

run and close to the lateral boundaries. The $\mathrm{CO}$ concentrations are underestimated in particular over the Atlantic Provinces and in the atmospheric boundary layer. When the predominant flow directions are considered, it is not likely that an underestimated inflow of $\mathrm{CO}$ across the lateral boundaries can be the main reason for the difference when compared with the measurements from flights A267, A268, and A270. The chemical decay rate for CO may be overestimated in the model; the product of the pressure dependent reaction rate coefficient between $\mathrm{CO}$ and $\mathrm{OH}$, and the $\mathrm{OH}$ radical concentration, determines this rate. The calculated average $\mathrm{OH}$ concentration for the whole model domain for the August 1993 calculation is about $2 \times 10^{6}$ molecules $/ \mathrm{cm}^{3}$ in the layer centered around $800 \mathrm{~m}$ but higher for midlatitudes where the flights took place, and about $20 \%$ of that level as an average for the layer cen- tered around $10,500 \mathrm{~m}$. If this is an overestimate of the $\mathrm{OH}$ concentrations, the calculated $\mathrm{CO}$ concentrations will be lower than the measured ones. The best agreement between measured and calculated $\mathrm{CO}$ is seen over the Atlantic (flights A267 and A270) where the travel time from the sources as well as from the lateral boundaries have been longer than in flights A268 and A269. The conclusions of this discussion are only speculative in nature: the total North American source term may be underestimated (anthropogenic and biogenic direct and indirect $\mathrm{CO}$ emissions), and the sink term related to the $\mathrm{OH}$ concentration may be somewhat overestimated.

It is seen in Figures 9-12 that the NO concentration is $0.1-3 \%$ of the $\mathrm{NO}_{y}$ concentration. The measured $\mathrm{NO}_{v}$ concentration is typically $1 \mathrm{ppb}$ and almost all measurements in the four flights fall between 0.5 and $1.5 \mathrm{ppb}$. The computed values resemble the measured ones, in particular during flight A269, but the measured concentrations are systematically a factor of 2 or more higher than the calculated ones. In the calculated $\mathrm{NO}_{y}$ concentration the main components are $\mathrm{NO}_{x}, \mathrm{PAN}$, and nitric acid, while nitrate aerosol is not included; nitrate aerosol is not expected to be the major $\mathrm{NO}_{y}$ component, however (in the model, nitric acid is transformed irreversibly to nitrate aerosol by a first-order decay process which is given a height dependent value; the concentration of nitrate aerosol is not explicitly calculated). The first-order decay assumed for $\mathrm{HNO}_{3}$ may be too efficient, which would contribute to the underestimation of $\mathrm{NO}_{v}$ in the model. Also in the case of the oxides of nitrogen and their products, the reasons for the underestimation in the model calculations are not clear and as for $\mathrm{CO}$, many factors are likely to contribute: the initial and boundary conditions (Figure 2) may be underestimated, the emission terms may be too low and the dispersion/dilution and removal processes too efficient.

\section{Plume Over the North Atlantic From the North American East Coast}

Continental plumes of polluted air are found downwind of the large sources of oxides of nitrogen, volatile organic compounds, and other pollutants on the North American east coast. These plumes eventually mix into the large-scale synoptic flow systems.

One situation with a flow toward the northeast of continental air over the North Atlantic was found on August 28, 1993. In Figure 13 a subregion of the $76 \times 72$ grid domain (Figure 1, area 3 ) is shown with the distribution of $\mathrm{CO}, \mathrm{NMHC}, \mathrm{NO}_{x}, \mathrm{NO}_{2}$, and $\mathrm{O}_{3}$ in model layer $3(\sim 800 \mathrm{~m})$. Vertical cross sections in the longitudinal direction of the plume off the North American continent are also shown for the height range from the surface and up to $5000 \mathrm{~m}$. There is a maximum in the concentration of the precursors $\mathrm{CO}$, $\mathrm{NMHC}$, and $\mathrm{NO}_{x}$ over Washington D. C. and northeastward along the eastern corridor, and a falloff in concentration with distance from the coast of New England. The falloff with distance from the main sources is particularly marked for $\mathrm{NO}_{x}$ which has the shortest chemical lifetime, while NMHC and in particular $\mathrm{CO}$ are calculated to have a slower reduction in concentration. For $\mathrm{NO}_{y}$, which is mainly secondary products (nitrate aerosol was not included in the calculated values) and ozone there are extended plumes out over the ocean with maximum concentrations around $1000 \mathrm{~m}$ above sea level (asl). In the marine boundary layer the concentrations are lower, which shows that the warmer continental air flows on top of the colder air masses next to the ocean surface, where the advection field can be considerably different from the flow field in the lower free troposphere. 

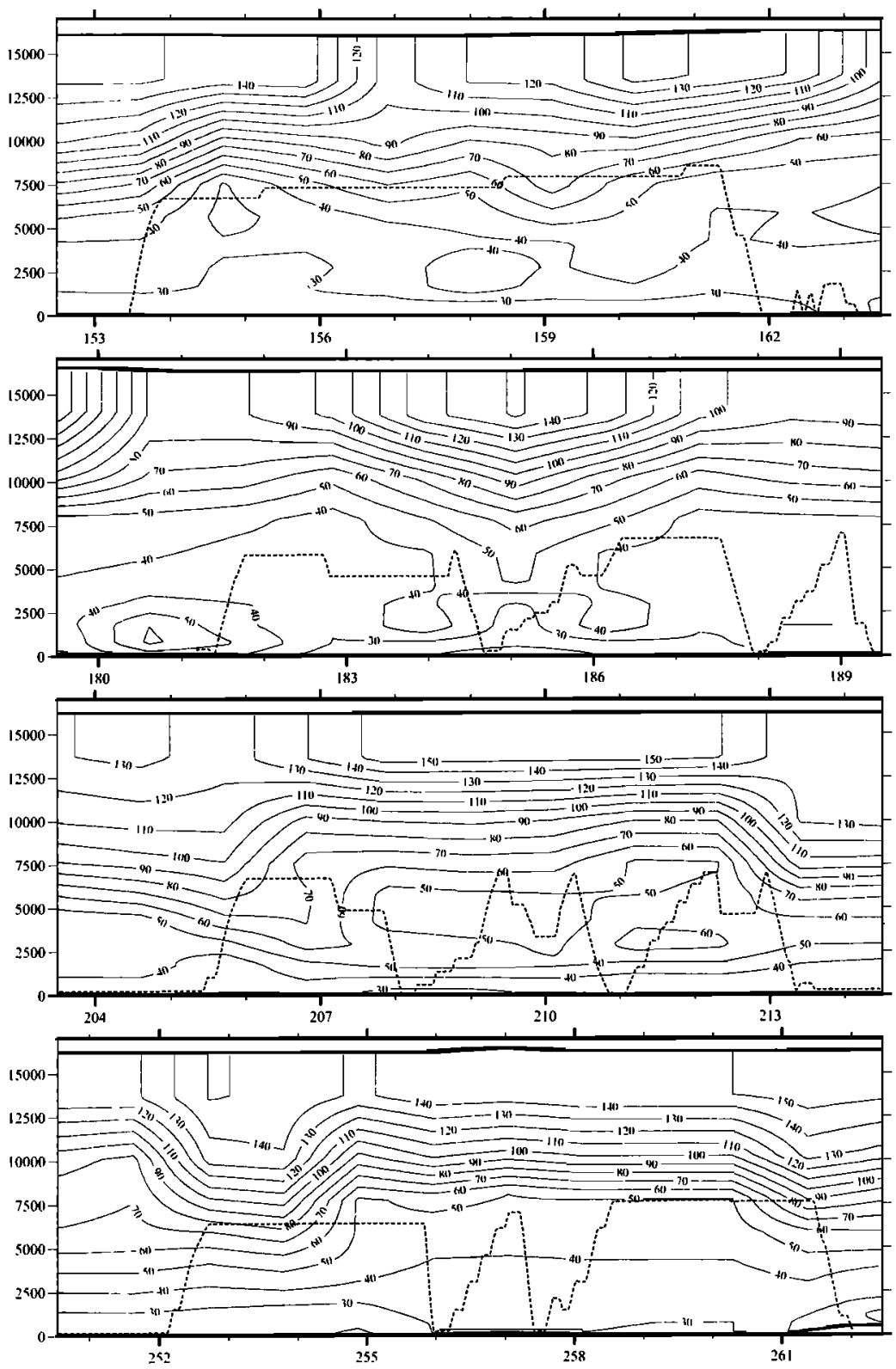

Figure 8. Vertical column of modeled ozone concentration (parts per billion by volume) along the OCTA flights. Panel 1, flight A267, between 0900 UT and 1900 UT, August 24 (153-163 hours after the start of the integration). Panel 2, A268, between 1200 UT and 2100 UT, August 25 (180-189 hours). Panel 3, A269, between 1200 UT and 2200, UT August 26 (204-214 hours). Panel 4, A270, between 1100 UT and 2200 UT, August 28 (251-262 hours).

For $\mathrm{CO}$ the concentrations in the plume over the sea are calculated to exceed $200 \mathrm{ppb}$ around $1000 \mathrm{~m}$ asl. On August 28 the Hercules aircraft headed back across the Atlantic toward the Azores (see Figure 1) and the measurements from the aircraft are not directly comparable with the calculations; the plume situation identified in the calculations for August 28 is nevertheless shown since it was the best example of a continental plume off North America in the simulation. From Figure 12 it is seen that during the climb after takeoff of flight A270 on August 28, CO levels up to $200 \mathrm{ppb}$ were measured; in flight A269 three days earlier around the Atlantic Provinces, between about 125 and $240 \mathrm{ppb}$ of $\mathrm{CO}$ were measured, with the highest concentrations found in or close to the atmospheric boundary layer (compare Figures 8 and 10 ).
For $\mathrm{NO}_{1}$, the measured concentrations in flights $\mathrm{A} 268$ and A269 (Figures 10 and 11 ) were typically around $1 \mathrm{ppb}$ with some values down to about $0.5 \mathrm{ppb}$ and up to $1.5 \mathrm{ppb}$. The calculated concentrations along the flight tracks are seen to be lower than the measured values. But it appears from Figure 13 that on August 28, in the continental plume off North America, up to 6-7 ppb of $\mathrm{NO}_{y}$ is calculated above the marine boundary layer, and values higher than 1-1.5 ppb are found up to $2500 \mathrm{~m}$ a.s.l. and extending more than $1000-1500 \mathrm{~km}$ downwind of the main sources of $\mathrm{NO}_{x}$ and VOC.

The ozone plume at level $3(\sim 800 \mathrm{~m})$ extends over $1500 \mathrm{~km}$ from the precursor emission regions and south of Newfoundland, and the ozone concentration maximum is found about $1000 \mathrm{~km}$ downwind of the main sources. This corresponds to about 2 days 

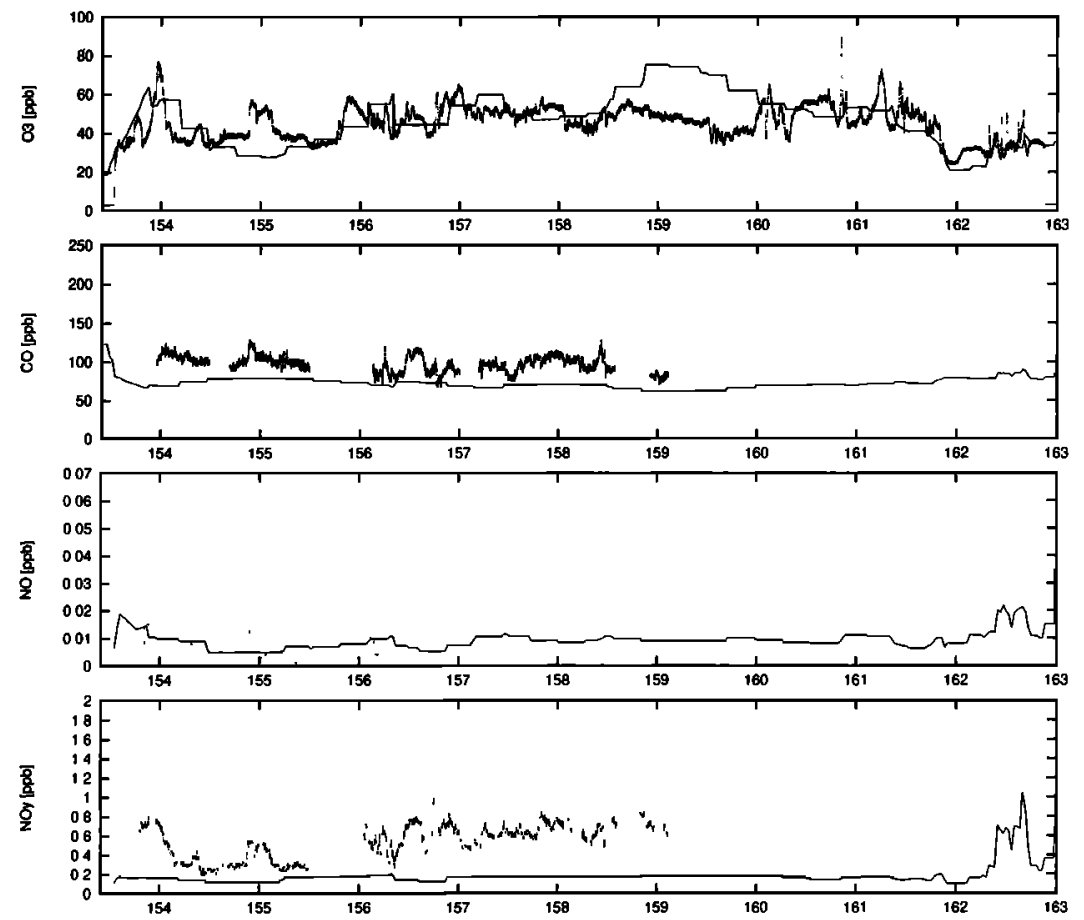

Figure 9. Measured and modeled concentrations along OCTA flight A267, August 24, 1993.

of transport time from the sources. In the vertical cross section through the continental plume it is seen that there is a strong gradient in ozone with height in the lowest $1 \mathrm{~km}$ over the ocean, with more than $80 \mathrm{ppb}$ around $1 \mathrm{~km}$ and below $35 \mathrm{ppb}$ at the ocean surface. Ozone is not efficiently deposited over sea surfaces, and the gradient in height is created when the warmer continental air masses move on top of the marine surface layer. Any ground mea- surements of ozone on islands northeast of New England or Haljfax would probably only measure low concentrations in marine air, while the elevated ozone concentrations due to continental emissions would pass aloft.

In the bottom diagram in Figure 13 the net chemical formation of ozone is shown in parts per billion per hour in the early afternoon local time on August 28, 1993. There is a maximum in the
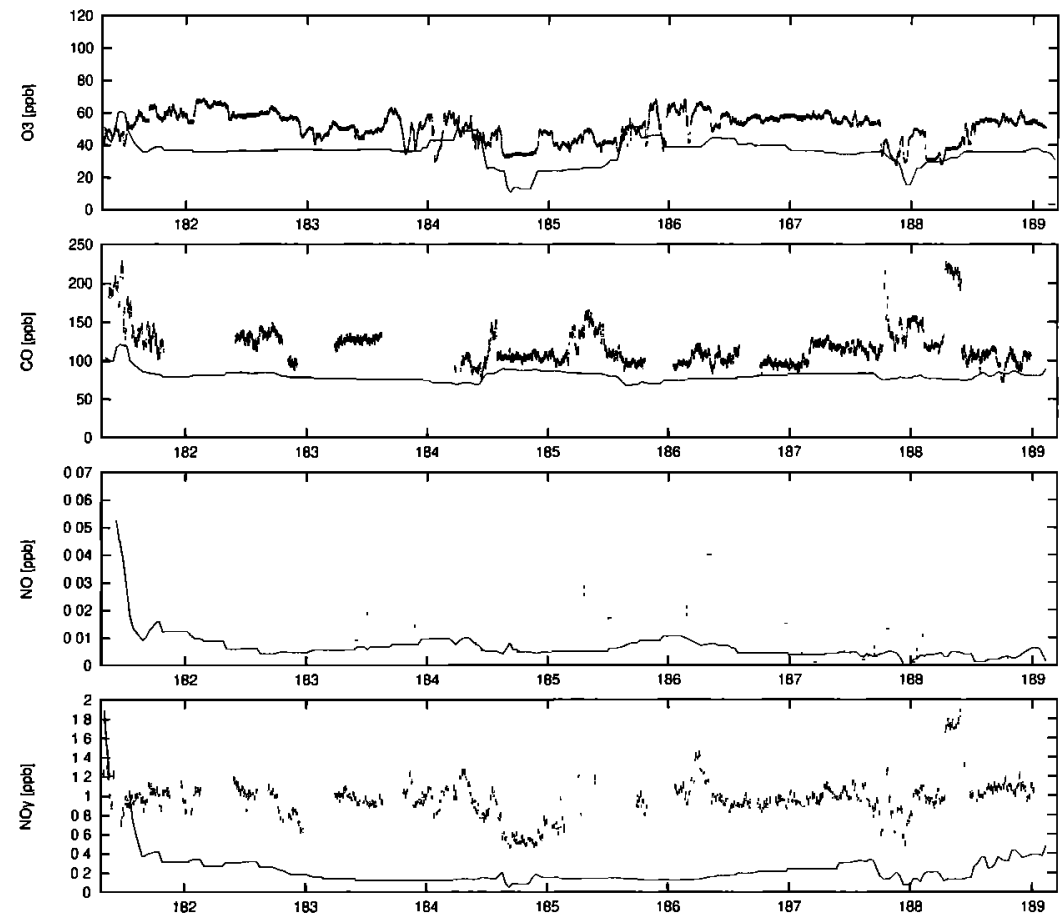

Figure 10. Measured and modeled concentrations along OCTA flight A268, August 25, 1993. 

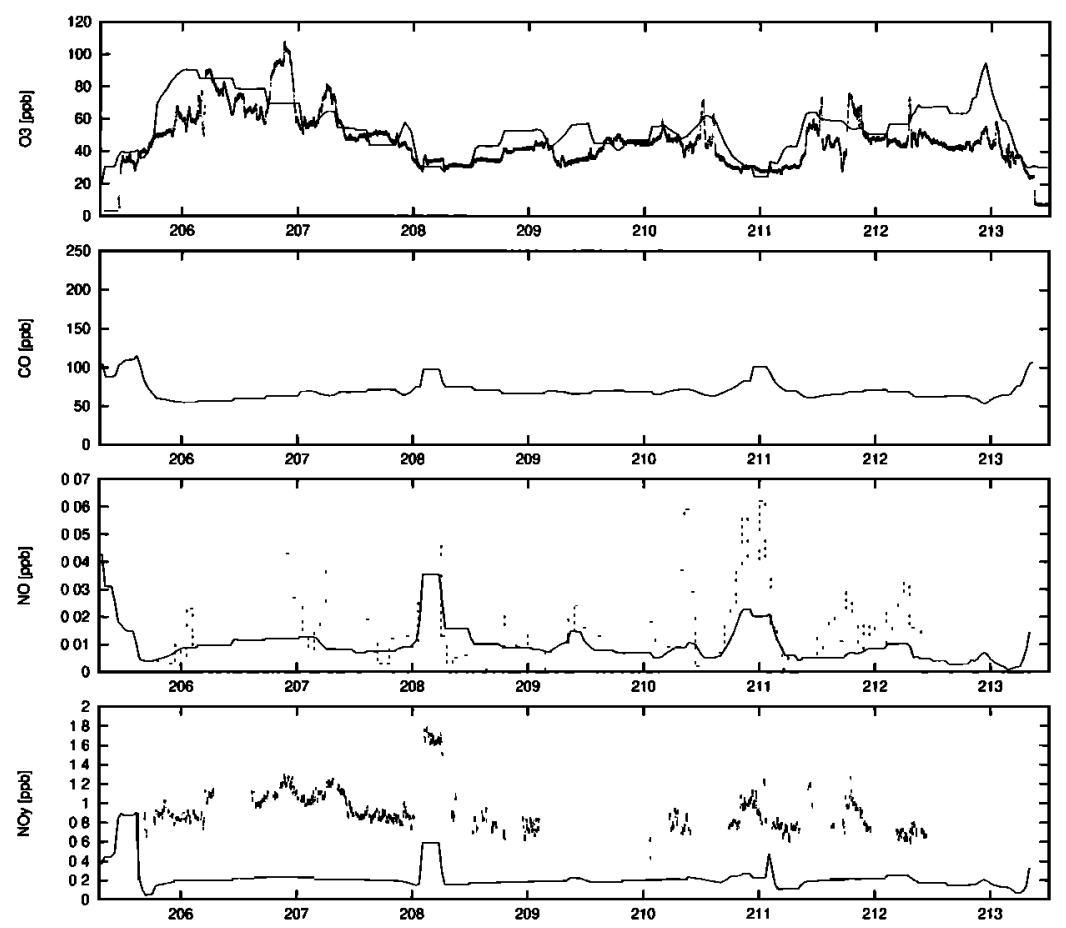

Figure 11. Measured and modeled concentrations along OCTA flight A269, August 26, 1993.

net chemical formation of about $2.5 \mathrm{ppb} / \mathrm{h}$ at $1 \mathrm{~km}$ and about 6.0 $\mathrm{ppb} / \mathrm{h}$ at the surface (not shown) just downwind of the main source region emissions, while about $500 \mathrm{~km}$ farther away from the sources, the net formation rate is about $0.5 \mathrm{ppb} / \mathrm{h}$ at $\sim 1200 \mathrm{~m}$ altitude. It can be seen that the region of maximum net chemical formation rate of ozone is displaced to a somewhat lower altitude in the atmospheric boundary layer than the plume of maximum ozone concentration. This reflects that the loss processes for ozone are more efficient close to the surface than higher up in the boundary layer or in the free troposphere (surface removal). The value of $6 \mathrm{ppb} / \mathrm{h}$ is approximately the same as one that has been calculated in the European boundary layer in ozone episodes [e.g. Flatoy et al., 1995], while the net ozone formation (destruction) in the free troposphere is often $0+/-0.1 \mathrm{ppb} / \mathrm{h}$.
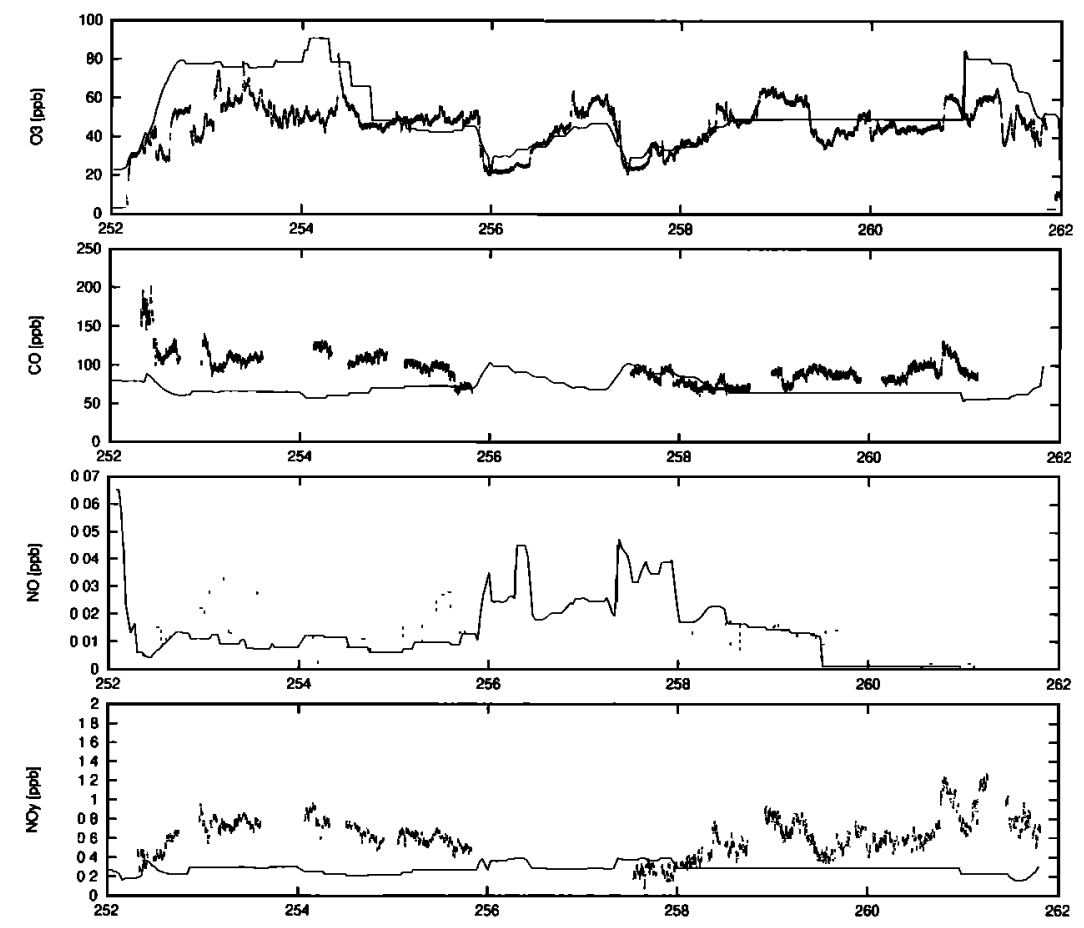

Figure 12. Measured and modeled concentrations along OCTA flight A270, August 28, 1993. 

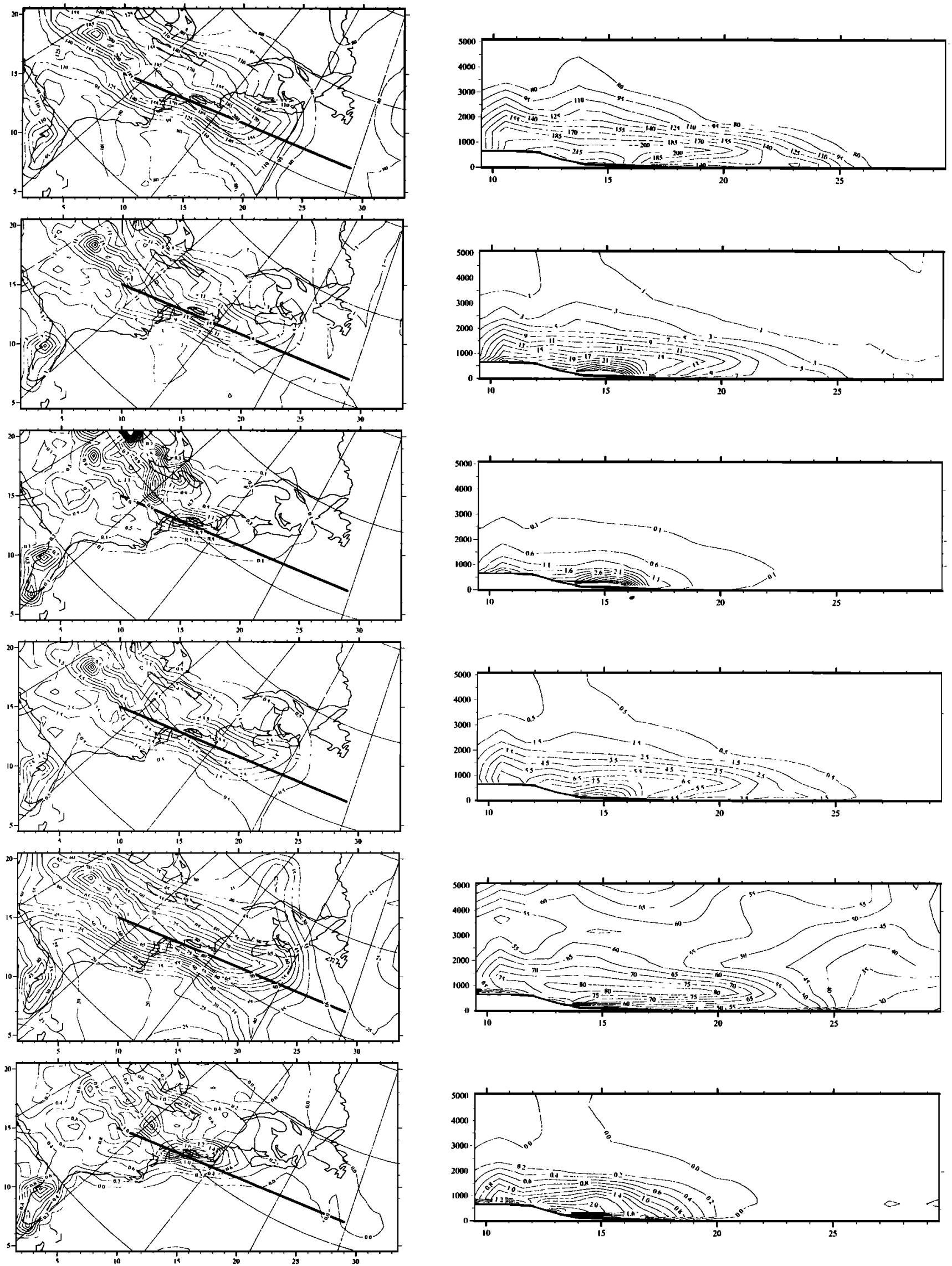

Figure 13. Situation at 1400 UT, August 28, 1993 (254 hours). (Left) Concentration (ppb) of CO, NMHC (ppbC), $\mathrm{NO}_{x}, \mathrm{NO}_{y}, \mathrm{O}_{3}$, and net $\mathrm{O}_{3}$ production from chemistry (ppb/h) at the model layer centered around $\sim 800 \mathrm{~m}$. (Right) Corresponding vertical cross sections. Position of cross section outlined in left panels. 
Figure 13 shows that in a weather situation with zonal advection and limited vertical motion the continental plume from North America can be traced in the calculation for 2-3 days into the North Atlantic when the concentration of $\mathrm{O}_{3}, \mathrm{CO}, \mathrm{NMHC}$, or the oxides of nitrogen are considered. Farther away, it is likely to be difficult to detect a regular continental plume, but layers may be encountered in the free troposphere with elevated concentrations of precursors like $\mathrm{CO}$ as well as $\mathrm{O}_{3}$ and other oxidant products which have originated over the North American continent. One additional example of this is seen in Figure 8, panel 3, and Figure 11 , panel 1 .

\subsection{Mass Fluxes of Oxides of Nitrogen, $\mathrm{CO}$, and Ozone off the North American Continent and Across Europe}

The influence of North American (and European) emissions on the midlatitude budget of oxides of nitrogen, carbon monoxide, and ozone was further investigated by carrying out calculations of the total mass flux of these compounds across the vertical boundaries of parts of the model domain; one volume covering North America and one volume covering Europe and the European part of Russia (see Figure 14), for the August 18-31, 1993, period. For each of the four vertical boundaries of each region the net mass flux of oxides of nitrogen, $\mathrm{CO}$, and ozone was calculated from the surface to the model top. The first four days of the integration were not included in the mass flux calculation because that is approximately the relaxation time for the boundary and initial conditions, which are not so well defined, inside the model domain toward a state where emissions, chemical processes, removal, and redistribution balance. Figure 14 also shows the average 500-hPa wind for the August 18-31, 1993, integration. It can be seen that the flow on the average is quite zonal in midlatitudes, with a ridge in the eastern Atlantic and a trough over central Europe and northern Pacific. Boundaries a and $c$ for North America follow approximately the western and eastern coastlines, while boundary $b$ is oriented toward the Arctic and boundary $d$ is one grid distance away from the lateral boundary condition. In a similar way, for Europe, boundaries $d$ and a are the westem and eastern boundaries, respectively, with a significant component of the horizontal wind perpendicular to the surfaces, while boundary $b$ is the southern boundary condition and $\mathrm{c}$ is also a southern boundary facing Africa and oriented fairly parallel to the horizontal flow if the zonal wind component is dominant.

In Table 2, mass fluxes of $\mathrm{NO}_{x}, \mathrm{NO}_{1}, \mathrm{CO}$, and ozone are given for the August 1993 period and for the four boundaries of each region shown in Figure 14 integrated over the vertical extent of the model domain (up to about $15 \mathrm{~km}$; see Figure 2). All numbers are in mass flux per year, where the average for the period of calculation is scaled to become an annual flux number. Also shown are the mass fluxes for two other time periods where model calculations have been carried out [Flatøy and Hov, 1996b]. These time periods were from October 26 to November 12, 1994, and from June 18 to July 7,1995 , and as before, the contribution to the mass fluxes during the first four days of integration was skipped. The

Figure 14. The average $500-\mathrm{hPa}$ wind fields for the simulation periods. Panel 1, August 22 to 30, 1993. Panel 2, October 30 to November 12, 1994. Panel 3, June 22 to July 7, 1995. The first four days of the simulation are considered as spin-up for the chemistry computations and are skipped. Also shown are the continental lateral boundaries used in Table 2 .
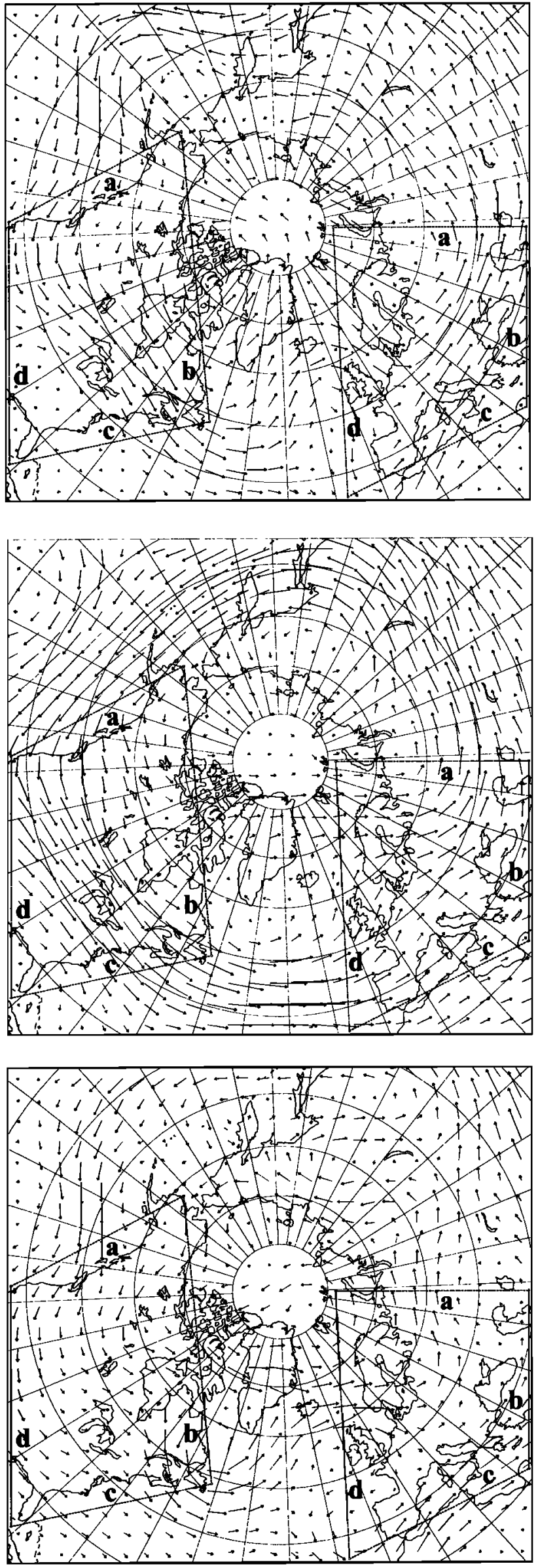
Table 2. Mass Transport Through the Vertical Boundaries of North America and Europe Given in Figure 14

\begin{tabular}{|c|c|c|c|c|c|c|c|c|c|c|}
\hline & \multicolumn{5}{|c|}{ North America } & \multicolumn{5}{|c|}{ Europe } \\
\hline & $\mathbf{a}$ & b & c & d & $\Sigma$ & a & b & c & d & $\Sigma$ \\
\hline \multicolumn{11}{|c|}{ August 22 to $30,1993$. Full model } \\
\hline $\mathrm{NO}_{x}$ & 184.7 & -176.4 & -449.7 & 267.2 & -174.1 & -446.7 & -216.9 & 108.2 & 147.3 & -408.2 \\
\hline $\mathrm{HNO}_{3}$ & 1196.0 & -638.9 & -1974.7 & 454.6 & -962.9 & -1847.7 & -1133.0 & 818.0 & 574.6 & -1588.0 \\
\hline $\mathrm{NO}_{?}$ & 1998.6 & -1104.5 & -3375.6 & 722.5 & -1759.0 & -3944.1 & -1793.7 & 1096.6 & 1154.4 & -3486.6 \\
\hline $\mathrm{CO}$ & 407.8 & -123.5 & -395.4 & 125.9 & 14.8 & -318.3 & -194.4 & 207.1 & 305.3 & -0.3 \\
\hline $\mathrm{O}_{3}$ & 736.0 & -327.4 & -717.7 & 136.6 & -171.6 & -778.6 & -443.5 & 518.5 & 479.8 & -223.8 \\
\hline \multicolumn{11}{|c|}{ August 22 to 30, 1993. No North American Emissions } \\
\hline $\mathrm{NO}_{r}$ & 215.1 & -155.2 & -342.8 & 190.8 & -92.1 & -450.3 & -223.8 & 111.2 & 143.9 & -419.0 \\
\hline $\mathrm{HNO}_{3}$ & 1254.1 & -467.9 & -1003.0 & 670.5 & 453.6 & -1845.5 & -1137.5 & 824.8 & 470.2 & -1688.1 \\
\hline $\mathrm{NO}_{y}$ & 2106.7 & -793.8 & -1965.1 & 918.8 & 266.5 & -3927.1 & -1807.7 & 1120.7 & 887.3 & -3726.9 \\
\hline $\mathrm{CO}$ & 408.6 & -117.7 & -374.6 & 130.6 & 46.9 & -317.9 & -194.3 & 207.4 & 299.3 & -5.5 \\
\hline $\mathrm{O}_{3}$ & 738.4 & -317.3 & -682.4 & 145.2 & -116.2 & -777.7 & -443.8 & 519.5 & 467.7 & -234.3 \\
\hline \multicolumn{11}{|c|}{ October 30 to November 12,1994} \\
\hline $\mathrm{NO}_{x}$ & 410.9 & -358.3 & -1704.7 & 533.7 & -1118.5 & -1764.4 & -246.9 & -66.8 & -1670.4 & -3748.5 \\
\hline $\mathrm{HNO}_{3}$ & 2096.2 & -1979.2 & -5143.8 & 2002.4 & -3024.4 & -4653.5 & -633.4 & -248.9 & 1766.1 & -3769.7 \\
\hline $\mathrm{NO}_{1}$ & 3662.0 & -3376.4 & -8927.6 & 2837.3 & -5804.7 & -8611.0 & -1399.2 & -444.0 & 2077.4 & -8376.9 \\
\hline $\mathrm{O}_{3}$ & 1054.9 & -495.3 & -1305.3 & 741.2 & -4.5 & -1294.2 & -276.7 & -33.3 & 1478.2 & -125.9 \\
\hline \multicolumn{11}{|c|}{ June 22 to July 7, 1995} \\
\hline $\mathrm{NO}_{1}$ & 98.9 & -101.2 & -489.5 & 343.4 & -148.5 & -297.6 & -275.8 & 149.5 & 133.1 & -290.8 \\
\hline $\mathrm{HNO}_{3}$ & 794.5 & -359.0 & -2080.2 & 1019.4 & -625.4 & -1009.9 & -1217.0 & 802.0 & 198.7 & -1226.2 \\
\hline $\mathrm{NO}_{1}$ & 1346.1 & -826.4 & -3868.4 & 1483.1 & -1865.7 & -2575.5 & -2108.0 & 1185.4 & 984.5 & -2513.7 \\
\hline $\mathrm{O}_{3}$ & 449.6 & -72.3 & -813.6 & 321.3 & -115.1 & -773.1 & -481.2 & 452.3 & 666.3 & -135.8 \\
\hline
\end{tabular}

$\mathrm{NO}_{\mathrm{r}}, \mathrm{HNO}_{3}$ and $\mathrm{NO}_{1}$ as $\mathrm{kt} \mathrm{NO}_{2} / \mathrm{yr}$. $\mathrm{O}_{3}$ and $\mathrm{CO}$ as $\mathrm{Mt} / \mathrm{yr}$. $\mathrm{NO}_{1}$ is defined as $\mathrm{NO}_{\mathrm{r}}+\mathrm{HNO}_{2}+\mathrm{HO}_{2} \mathrm{NO}_{2}+\mathrm{PAN}+\mathrm{NO}_{3}+2 \mathrm{~N}_{2} \mathrm{O}_{5}+\mathrm{HNO}_{3}$; nitrate aerosol is not calculated and therefore not included.

mean horizontal advection fields on the 500-hPa surface for the October 1994 and June 1995 periods of calculation are shown in Figure 14. In October 1994 there was a significant interruption in the zonal flow across the North Atlantic with a trough south of Greenland and Iceland and a ridge over northern Europe. In June 1995 there was a trough south of Greenland, a ridge in the middle North Atlantic and a trough over central Europe and a ridge west of the British Isles, again with significant deviation from zonal flow across the North Atlantic with significant meridional as well as vertical components in the advection field. The average flow fields for the free troposphere are shown to give a picture of the variability in the flow from North America toward Europe and, consequently, in the transit time and dispersion of chemical trace species.

For the species with falling mixing ratio with height, the numbers in Table 2 reflect largely the lower-tropospheric mass flux, while in the case of ozone, there is a significant contribution to the mass flux from the tropopause region.

In August 1993 the flux of $\mathrm{NO}_{v}$ across eastern North America (boundary c) was $24.2 \%$ of the North American $\mathrm{NO}_{x}$ emissions inside the model domain. Of this flux, $\mathrm{HNO}_{3}$ made up $14.1 \%$ and PAN about $6.9 \%$, while $\mathrm{NO}_{x}$ was only $3.3 \%$, reflecting its short chemical lifetime. The fraction $24.2 \%$ can be compared with the number $25-30 \%$ calculated by Brost et al. [1988] for a similar flux based on April 1982 meteorology. The magnitude of the mass flux across the southern boundary of the North American region is mainly caused by the boundary conditions, which are fixed (see Figure 2). For August 1993 this flux of $\mathrm{NO}_{y}$ is equal to about $5.2 \%$ of the anthropogenic $\mathrm{NO}_{r}$ emissions from the North American surface sources inside the model domain. It is further seen in Table 2 that the $\mathrm{NO}_{v}$, flux across the western North American continent (boundary a) is positive and equal to about $14.3 \%$ of the $\mathrm{NO}_{x}$ emissions inside the North American region. The net loss of $\mathrm{NO}_{v}$ through the lateral boundaries around North America is about $12.6 \%$ of the North American $\mathrm{NO}_{r}$ emissions.

For Europe, the mass flux of $\mathrm{NO}_{v}$, through the western boundary (d in Figure 14) was $1.154 \mathrm{Mt}\left(\mathrm{NO}_{2}\right) / \mathrm{yr}$ based on the August 1993 run. The mass flux of $\mathrm{NO}_{y}$ out of the North American continent was $3.371 \mathrm{Mt}\left(\mathrm{NO}_{2}\right) / \mathrm{yr}$ through boundary $\mathrm{c}$ and 1.104 $\mathrm{Mt}\left(\mathrm{NO}_{2}\right) / \mathrm{yr}$ through boundary b, or $4.475 \mathrm{Mt}\left(\mathrm{NO}_{2}\right) / \mathrm{yr}$ as the sum of the mass fluxes through the boundaries facing the east. It should be recalled that the mass fluxes are integrated throughout the height of the model domain (about $15 \mathrm{~km}$ ) and it can be concluded that the import of $\mathrm{NO}_{1}$. across the western boundary of Europe is only a small fraction of the export from North America of $\mathrm{NO}_{y}$.

For Europe it is seen that the mass flux of $\mathrm{NO}_{y}$, out of the region through the eastern boundary (a in Figure 14) was 22.1\% of the European $\mathrm{NO}_{x}$ emissions, while there was a net flux into the vol- 
ume from the Atlantic (boundary d) and through the southern boundary $c$. There was a loss through the southeastern boundary b. The mass flux was dominated by PAN and $\mathrm{HNO}_{3}$, while the flux of $\mathrm{NO}_{x}$ was small in comparison. For Europe the net export of $\mathrm{NO}_{y}$ was $19.6 \%$ of the European emissions. Based on the October 1994 and June 1995 calculations the fraction was $31.4 \%$ and $16.5 \%$, respectively. These numbers can be compared with the fraction of European $\mathrm{NO}_{x}$ emissions which has been calculated to be deposited inside the EMEP model domain (Europe, including the western part of Russia) on an annual basis; this number was calculated to be $61 \%$ for 1989 [Hov and Hjollo, 1994], while the remaining $39 \%$ either were advected out of the model domain through the lateral boundaries, vented into the free troposphere, or remained airborne inside the model domain.

For the model period in October 1994 the net fluxes of $\mathrm{NO}_{y}$ out of North America and Europe relative to the emissions within the respective regions were much higher than in August 1993 (or in June 1995); the fractions were 27.8 and $31.4 \%$ for North America and Europe, respectively. For the eastern boundary of North America (c in Figure 14) the mass flux of $\mathrm{NO}_{y}$ was $42.7 \%$ of the North American emissions; for Europe through boundary a the fraction was $31.4 \%$. The mass fluxes out of the regions are larger in the October calculation because the removal processes then are slower (less deposition) and the horizontal winds are higher. In June 1995 the numbers are more comparable to thè August 1993 case.

For $\mathrm{CO}$ the fluxes through the lateral boundaries of North America and Europe in August 1993 almost balance; there is a net flow into North America which is only about $3 \%$ of the mass flux through the western lateral boundary a, and for Europe the residual is almost zero $(-0.3 \mathrm{Mt}(\mathrm{CO}) / \mathrm{yr})$. This means that the chemical source and sink terms almost are in balance within both North America and Europe. The flux into North America across boundary a was almost equal to the flux out of North America through boundary c (6.5 and 6.3 times the North American CO emissions, respectively). This shows that with the initial and boundary conditions chosen and for the emission inventory used, the CO distribution was close to steady state in August 1993 in North America and Europe (horizontal flux into the continent plus emissions equal horizontal flux out of the continent plus chemical decay).

The ratio (flux into Europe through boundary d) / (flux out of North America through boundaries $b$ and $c$ ) is an indicator of the chemical lifetime of a given compound or group of compounds relative to other compounds; for the August 1993 period the ratio was 0.58 for $\mathrm{CO}, 0.46$ for $\mathrm{O}_{3}, 0.24$ for $\mathrm{NO}_{x}, 0.26$ for $\mathrm{NO}_{y}, 0.22$ for $\mathrm{HNO}_{3}$, and 0.31 for $\mathrm{NO}_{v}-\mathrm{HNO}_{3}$ (mainly PAN). Nitric acid and oxides of nitrogen were thus calculated to be reduced in horizontal mass flux across the North Atlantic much faster than CO or ozone. It should be remembered that for ozone a substantial part of the mass flux took place in the upper troposphere where the lifetime of ozone is long (of the order of 100 days).

It can be seen from Table 2 that there is a considerable horizontal divergence of ozone both over North America and Europe for the August 1993 period. Translated into annual numbers, the net horizontal flux was about $172 \mathrm{Mt} / \mathrm{yr}$ out of North America and $224 \mathrm{Mt} / \mathrm{yr}$ out of Europe, or about $25-30 \%$ of the mass flux through the lateral boundary with the highest flux. The horizontal divergence is balanced by flux from the stratosphere, ground removal and by the net chemical source inside North America and Europe, respectively. The net flux of ozone out of the subregions was much smaller in the October 1994 case (Table 2); the mass flux was only $4.5 \mathrm{Mt} / \mathrm{yr}$ out of North America and $126 \mathrm{Mt} / \mathrm{yr}$ out of Europe. These numbers reflect the different season and meteo- rological conditions; the horizontal wind velocities were higher in October giving rise to much higher mass fluxes of ozone through the lateral boundaries which were oriented north-south. The transit times across the continents were apparently much shorter than in August 1993, however, with less time available for photooxidant formation. It is likely that also other physical parameters were less favorable for ozone formation (larger solar zenith angle, lower temperatures). In June 1995 the mass fluxes for ozone and other compounds were smaller than in August 1993, indicating that the horizontal wind speeds on average were lower than in August 1993 or, in particular, during October 1994.

The August 1993 time period was also run without emissions of $\mathrm{NO}_{x}$, VOC, or CO from anthropogenic sources in North America. This was done to identify the theoretical influence of North American emissions on the fluxes of trace species across the North Atlantic and over Europe. In Table 2 it is seen that the upwind mass fluxes (across boundary a) for North America were calculated to increase somewhat in this case. This is an indication that without the North American anthropogenic emissions the concentration of the hydroxyl radical was calculated to drop in the northern hemisphere midlatitude troposphere. There was a considerable drop in the mass fluxes out of North America and also across the lateral boundary $\mathrm{d}$ since the flux there is into the region (almost unchanged) in some places and out of the region (large change) in other places. It is interesting to note, however, that the changes in mass fluxes across boundary $d$ (the upwind boundary) for Europe were not dramatic. The largest change in mass flux over Europe was found for $\mathrm{HNO}_{3}$ and $\mathrm{NO}_{y}$ through the upwind boundary; these fluxes changed from $575 \mathrm{kt} / \mathrm{yr}$ to $470 \mathrm{kt} / \mathrm{yr}$ and $1154 \mathrm{kt} / \mathrm{yr}$ to $887 \mathrm{kt} / \mathrm{yr}$ as $\mathrm{NO}_{2}$, respectively. For the sum of mass flux through the lateral boundaries the changes were less than $7 \%$ for the compounds in Table 2 over Europe, while over North America the changes were substantial (change in sign). These calculations indicate that for the August 1993 time period the horizontal divergence of species like ozone and oxides of nitrogen over Europe is not strongly influenced by the North American emissions.

\section{How Significant is the Choice of Initial and Upper Boundary Conditions for Species Like Ozone for the Calculated Free Tropospheric Chemical Composition?}

It is seen above that the calculated and measured concentrations of trace species like $\mathrm{NO}$, the sum $\mathrm{NO}_{3}$, ozone, and $\mathrm{CO}$ can differ significantly in the free troposphere, even though the description of the meteorological situation is quite realistic. Many reasons for the differences have been discussed above and can be related to not well-defined initial and boundary conditions for the chemical trace species, coarse model resolution, inaccurate determination of trace gas emissions, and chemical production and loss terms. In the atmospheric boundary layer the chemical formation rate of ozone in photochemical episodes over polluted continents is so fast that the boundary and initial conditions are less important when an integration is carried out over several days.

To illustrate how the choice of the initial and boundary conditions for ozone influences the calculated ozone concentration distribution, two different calculations were carried out with the model. In the first calculation a high initial and boundary condition of ozone was chosen $\left(\mathrm{O}_{3}\right.$ high, Figure 2$)$, in the second calculation the low condition, which has been used in all the other calculations presented in this paper, was chosen $\left(\mathrm{O}_{3}\right.$ low, Figure 
2). Figure 15 (top two panels) shows the ozone concentration in the model layer centered around $\sim 10,500 \mathrm{~m}$ in these two model runs after 306 hours of simulation (1800 UT, August 30). The concentration patterns in the two figures resemble each other, but the numbers are more than doubled from the low initial ozone case to the high case in regions with descending ozone rich air.

Two more calculations were carried out to investigate how the concentration level of ozone affected the relationship between the net chemical formation rate of ozone and the concentration of $\mathrm{NO}_{\mathrm{r}}$ throughout the troposphere. The high and low ozone cases were run without lightning $\mathrm{NO}_{x}$ emissions. Figure 15 (bottom two panels) shows the difference in ozone concentration between the simulation with lightning emissions of $\mathrm{NO}_{x}$ and the simulation without, for both the high and the low ozone boundary cases for $\sim 10 \mathrm{~km}$ altitude after 306 hours. The two plots are quite similar, both showing increased ozone over the continents and in connection with the flow off the East Coast of North America. The transport acts to disturb the picture, and the locations with increased ozone concentrations (Figure 15) are not necessarily where the ozone has been produced. Areas with a low increase are either outside (or upwind) of the lightning emission areas or are experiencing descending air (see Figure 15). The largest differences in the ozone change are found in areas with large concentration differences (west of Ireland, west of Spain), but even there, the fields for the change in the concentration of ozone are quite similar.

Figure 15 gives a picture of the impact of lightning emissions on the ozone distribution. Most of the emissions take place over the continents and the plume of extra ozone over the North Atlantic is mainly due to lightning over North America. Over continental Europe a similar but weaker enhancement is noticed. The

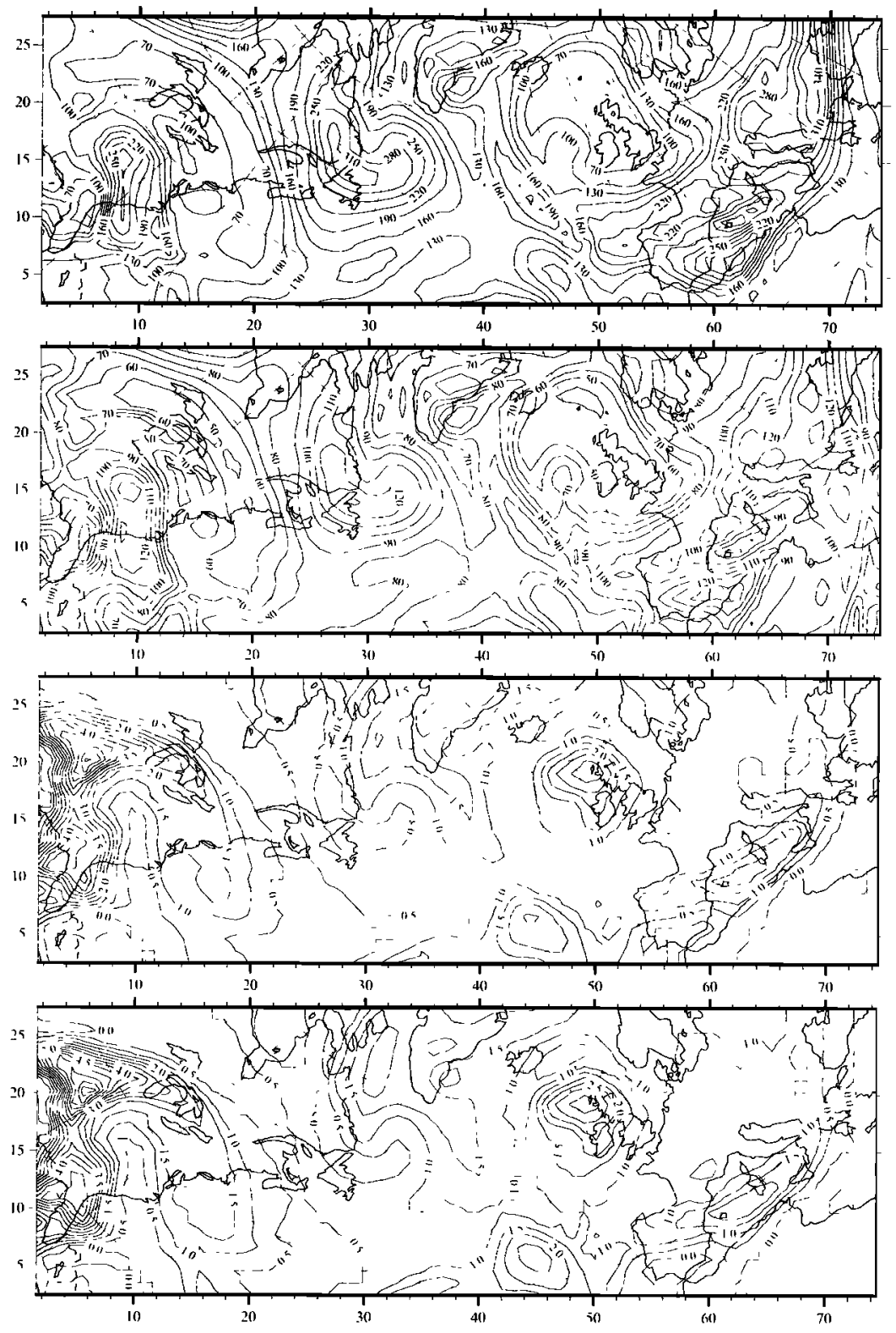

Figure 15. Panel l, ozone concentration (parts per billion per volume) at $\sim 10 \mathrm{~km}, 1800 \mathrm{UT}$, August 30 . Simulation with the high initial/boundary condition for ozone. Panel 2, simulation with the low initial/boundary condition. Panel 3 , change in ozone concentration between the simulation with the full model and the simulation without lightning emissions. Both with the high initial/boundary conditions for ozone. Panel 4 , same as panel 3 but with the low initial/ boundary conditions for ozone. 

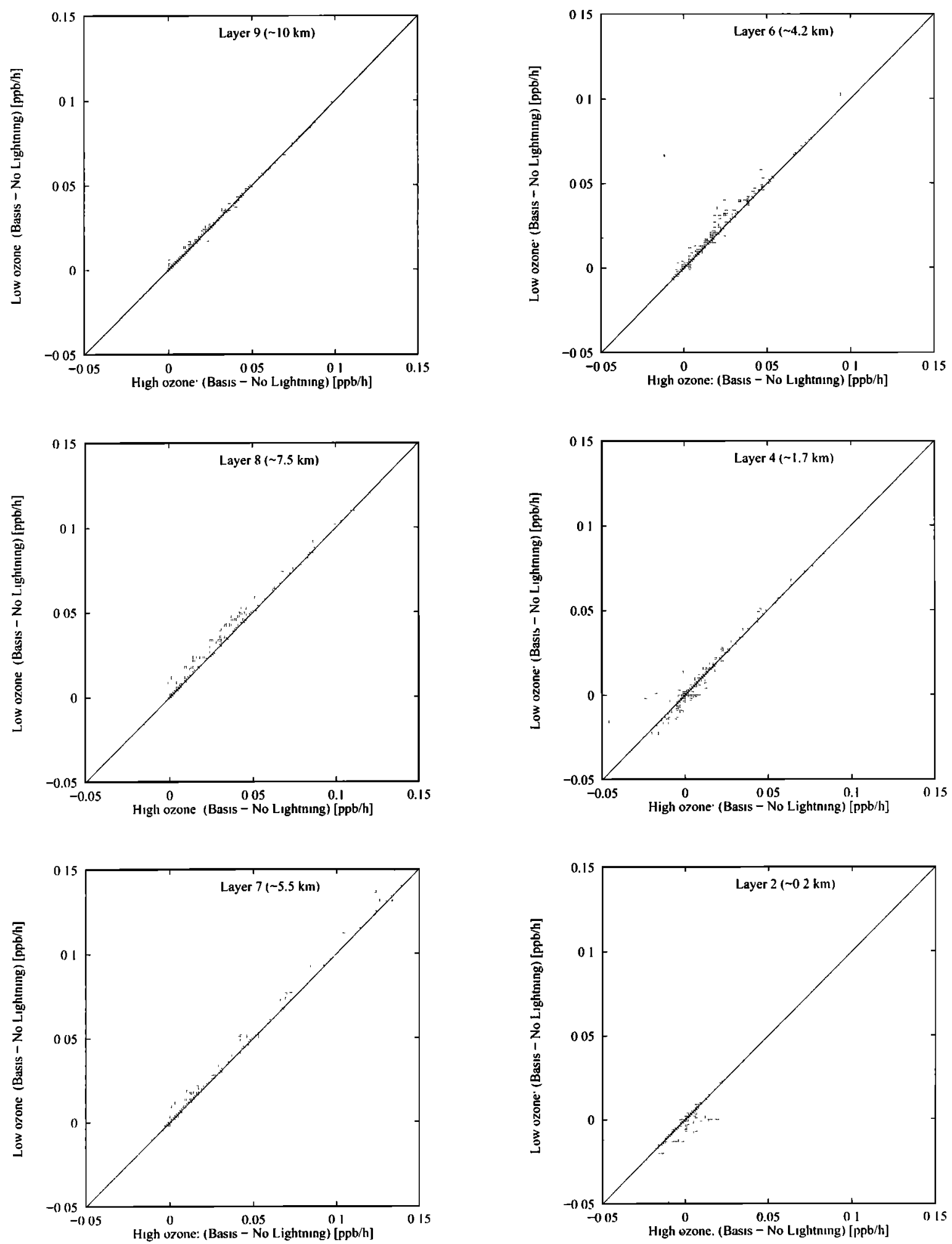

Figure 16. Scatterplot for $1800 \mathrm{UT}$, August 30 of the ozone net chemical formation rate when $\mathrm{NO}_{x}$ emission from lightning is included (basis) minus the ozone net chemical formation rate when $\mathrm{NO}_{x}$ emission from lightning is excluded (no lightning), for the low initial and boundary ozone case as a function of the high initial and boundary ozone case.

effect of $\mathrm{NO}_{Y}$ emissions in the free troposphere over North America can therefore be traced across the North Atlantic, but the enhancement in the ozone concentration is small (less than 5$10 \%$ ) and difficult to identify in measurements since the spatial variability in ozone is significant. Surface emissions of $\mathrm{NO}_{x}$ trans- ported upward by convection or aircraft emissions can contribute to similar ozone plumes.

The question "to what extent is the net change in the chemical formation rate of free tropospheric ozone which follows from a change in the concentration of $\mathrm{NO}_{x}$, dependent on the concentra- 
tion of ozone itself" is further addressed in Figure 16. Scatterplots are shown of the differences caused by the lightning emissions in the net chemical formation rate of ozone for the high and low ozone boundary conditions. The plots represent the same subarea as discussed in Figure 15, after 303 hours of simulation (1500 UT August 30 ) and for six different model layers. The scatterplot for layer 9 corresponds to Figure 15. It is seen that the change in the net chemical formation rate of ozone because of the change in $\mathrm{NO}_{x}$ emissions is somewhat higher for the case with the low ozone boundary condition compared to the case with the high boundary condition, but the $1: 1$ line in the scatterplots represents all the data points quite well in the upper and midtroposphere. This means that in the upper troposphere the net change in the chemical formation rate of ozone due to a change in the $\mathrm{NO}_{x}$ concentration is quite independent of the absolute value of the ozone concentration itself and, consequently, the choice of boundary conditions for ozone is not so important in this context. In the lower troposphere the relationship between $\Delta\left(\partial O_{3} / \partial t\right)$ and the $\Delta \mathrm{NO}_{x}$ concentration also depends on the $\mathrm{O}_{3}$ concentration, and the linearity seen in the upper layers (Figure 16) disappears in the boundary layer.

\section{Conclusions}

The variability in the concentrations of ozone in the free troposphere is mainly caused by dynamical processes, while the chemical modification is small over an integration time of less than 2 weeks. A continental plume off the North American continent extending $2000 \mathrm{~km}$ or more into the North Atlantic was identified toward the end of the period of calculation (August 18-30, 1993). There was a maximum in the concentration of ozone around $1 \mathrm{~km}$ above the sea surface, with a much lower concentration in the marine boundary layer close to the ocean surface. Some of the U.K. Meteorological Office Hercules C-130 measurements in the free troposphere off the Atlantic Provinces were used for model comparison. It is difficult to compute real-time concentration fields suitable for comparison with measurements, even in a coupled mesoscale chemical transport model with an accurate analysis and forecast of the actual weather situation. Not well-known initial and upper boundary conditions of species like ozone itself contribute strongly to the differences seen between model concentrations and measurements, but the grid resolution, emission data, and many other factors contribute to the discrepancies. The calculations indicate that in the upper troposphere the net change in the chemical formation rate of ozone due to a change in the $\mathrm{NO}_{3}$ concentration is quite independent of the absolute value of the ozone concentration itself and, consequently, the choice of boundary conditions for ozone, is not so important in this context. In the lower troposphere the change in the net chemical formation rate of ozone, which follows from a change in the concentration of $\mathrm{NO}_{x}$ shows a marked dependence on the concentration of ozone. This indicates that the study of ozone concentration changes in the upper free troposphere may be carried out in simple climatological models, while an accurate determination of the absolute concentration levels of ozone and other trace species requires that the initial and upper boundary conditions are well known.

Acknowledgments. This work was supported by the Norwegian Research Council, The Norwegian Supercomputing Committee (TRU), and the Nordic Council of Ministers. The work is a part of the EU projects OCTA (Oxidizing Capacity of the Tropospheric Atmosphere), POLINAT (pollution from aircraft emis- sions in the North Atlantic flight corridor), and TACIA (Testing Atmospheric Chemistry in Anticyclones) and is a contribution to NARE in the IGBP subproject IGAC. Funding for the ozonesonde measurements was provided by the NOAA Office of Global Programs, Atmospheric Chemistry Project.

\section{References}

Abatement of Nuisances Caused by Air Transport/European Civil Aviation Conference (ANCAT/ECAC): Emission inventory database group A global inventory of aircraft fuel and $\mathrm{NO}_{x}$ emissions for AERONOX, First AERONOX day, Dtsch. Luft und Raumfahrt Mitt., Cologne, Germany, 28 February 1995.

Benkovitz, C.M., M. T. Scholtz, J. Pacyna, L. Tarrasỏn, J. Dignon, E. C. Voldner, P. A. Spiro, J. A. Logan and T.E. Graedel, Global gridded inventories of anthropogenic emissions of sulfur and nitrogen, $J$. Geophys. Res., this issue.

Brost, R.A., R.B. Chatfield, J.P. Greenberg, P.L. Haagenson, B.G. Heikes, S. Madronich, B.A. Ridley, and P.R. Zimmerman, Three-dimensional modeling of transport of chemical species from continents to the Atlantic Ocean, Tellus. 40B, 358-379, 1988.

Buhr, M. P., M. Trainer, D. D. Parrish, R. E. Sievers, and F. C. Fehsenfeld, Assessment of pollutant emission inventories by principal component analysis of ambient air measurements, Geophys. Res. Lett., 19, 1009$1012,1992$.

Carmichael, G.R., L.K. Peters, and R.D. Saylor, The STEM-III regional acid deposition and photochemical oxidant model, I, An overview of model development and applications, Atmos. Environ., 25A, 20772090,1991

Chang, J.S., R.A. Brost, I.S.A. Isaksen, S. Madronich, P. Middleton, W.R. Stockwell, and C.J. Walcek, A three-dimensional Eulerian acid deposition model. Physical concepts and formulation, $J$ Geophys. Res, 92, $14,681-14,700,1987$

Fahey, D. W., C. S. Eubank, G. Hübler, and F. C. Fehsenfeld, Evaluation of a catalytic reduction technique for the measurement of total reactive odd-nitrogen $\mathrm{NO}_{4}$ in the atmosphere, J. Atmos Chem., 3, 435-468, 1985.

Flatoy, F., Balanced wind in advanced advection schemes when species with long lifetimes are transported, Atmos Environ.. 27A, 1809-1819, 1993.

Flatøy, F., Ø. Hov, and H. Smil, Three-dimensional model studies of exchange processes of ozone in the troposphere over Europe, J. Geophys. Res., 100, 11,465-11,481, 1995.

Flatøy, F., and $\emptyset$. Hov, Three-dimensional model studies of the effect of $\mathrm{NO}_{\mathrm{r}}$ emissions from aircraft on ozone in the upper troposphere over Europe and the North Atlantic, J. Geophys. Res, 101, 1401-1422, I996a.

Flatøy, F, and $\emptyset$. Hov, Model studies of the effects of aircraft emissions in the North Atlantic flight corridor during October 26 to November 13, 1994, and June 18 to July 5,1995 , contribution to the final report of POLINAT to the Commission of the European Communities, 1996b.

Galloway, J.N., D.M. Whelpdale, and G.T. Wolff, The flux of S and N eastward from North America, Atmos. Environ., 18, 2595-2607, 1984.

Gerbig, C., D. Kley, A. Volz-Thomas, J. Kent, K. Dewey, and D. S. McKenna, Fast response resonance fluorescence $\mathrm{CO}$ measurements aboard the C-130: Instrument characterization and measurements made during NARE 1993, J. Geophys. Res., this issue.

Grønås, S., A. Foss, and M. Lystad, Numerical simulations of polar lows in the Norwegian Sea, Tellus, 39A, 334-353, 1987.

Guenther, A.L., P.R.Zimmerman, P.C.Harley, R.K.Monson, and R.Fall, Isoprene and monoterpene emission rate variability. Model evaluations and sensitivity analyses, J. Geophys. Res., 98, 12,609-12,617, 1993.

Hass, H., A. Ebel, H. J. Jakobs, and M. Memmesheimer, Interaction of the dynamics and chemistry in photo-oxidant formation, in Proceedings of ELIROTRAC Symposium ' 94 on Transport and Transformation of Pollutants in the Troposphere, 65-68, edited by P. Borrell, P. M. Borrell, and W.Seiler, SPB Acad., The Hague, 1993.

Hough, A.M., The development of a two-dimensional tropospheric model. The model chemistry, J. Geophys. Res., 96, 7325-7362, 1991. 
Hov, Ø., and B.Aa. Hjøllo, Transport distance of ammonia and ammonium in northem Europe, 2, Its relation to emissions of $\mathrm{SO}_{2}$ and $\mathrm{NO}_{x}, J$. Geophys. Res., 99, 18,749-18,755, 1994.

Jacob, D. J., et al., Simulation of summertime ozone over North America, J. Geophys. Res., 98, 14,797-14,816, 1993.

Köhler., I., R. Sausen, and L. Gallardo Klenner, $\mathrm{NO}_{x}$ production by lightning, in The Impact of $\mathrm{NO}_{x}$ Emissions From Aircraft Upon the Atmosphere at Flight Altitudes $8-15 \mathrm{~km}$ (AERONOX), edited by U. Schuman, draft, final report to the Commission of the European Communities, Dtsch. Luft und Raumfahrt Mitt., Oberpfaffenhofen, Germany, pp. 343-345, 1995.

Kvamstø, N.G., Implementation of the Sundqvist scheme in the Norwegian limited area model, Meteorol. Rep. Ser., 2-92, Dep. of Geophys., Univ. of Bergen, Bergen, Norway, 1992.

Lerner, A., D. Kley, A. Volz-Thomas, and D. S. McKenna, Ozon-Stickoxid-Korrelationen in der Troposphäre, Ber. Forsch. Jül., Jül-3008. ISSN 0944 -2952, 1994.

Liu, M.K., R.E. Morris, and J.P. Killus, Development of a regional oxidant model and application to the Northeast United States, Atmos. Environ., $18,1145-1161,1984$.

Lubkert, B., and W. Schöpp, A model to calculate natural VOC emissions from forests in Europe, Rep. A-236I, Int. Inst. for Appl. Syst. Anal., Laxenburg, Austria, 1989.

Marenco, A., Large scale distributions of $\mathrm{O}_{3}, \mathrm{CO}$ and $\mathrm{CH}_{4}$ in the troposphere from scientific aircraft measurements (STRATOZ lII), in Tropospheric Ozone, edited by I.S.A. Isaksen, pp. 73-81, D. Reidel, Norwell, Mass., 1988.

Marenco, A., and F. Said, Meridional and vertical ozone distribution in the background troposphere $\left(70^{\circ} \mathrm{N}-60^{\circ} \mathrm{S} ; 0-12 \mathrm{~km}\right.$ altitude) from scientific aircraft measurements during the Stratoz III experiment (June 1984), Atmos. Environ., 23, 201-214, 1989.

McKeen, S. A., E.-Y. Hsie, M. Trainer, R. Tallamraju, and S.C. Liu, A regional model study of the ozone budget in the eastern United States, J. Geophys. Res., 96, 10,809-10,845, 1991.

Nordeng, T.E., Parameterization of physical processes in a three-dimensional numerical weather prediction model, Tech. Rep. 65. Norw. Meteorol. Inst., Oslo, 1986.

Pierson, W. R., A. W. Gertler, and R. L. Bradow, Comparison of the SCAQS tunnel study with other on-road vehicle emission data, J. Air Waste Manage. Assoc., 40, 1495-1504, 1990.
Sandnes, $\mathrm{H}$., Calculated budgets for airborne acidifying components in Europe, 1985, 1987, 1988, 1989, 1990, 1991, and 1992, EMEP MSC-W Rep. I/93, Tech. Rep. 109, Norw. Meteorol. Inst., Oslo, 1993.

Simpson, D., Long-period modelling of photochemical oxidants in Europe: A) Hydrocarbon reactivity and ozone formation in Europe, B) On the linearity of country-to-country ozone calculations in Europe, EMEP MSC-W Note 1/92, Norw. Meteorol. Inst, Oslo, 1992.

Smit, H.G.J., D. Kley, S. McKeen, A. Volz, and S. Gilge, The latitudinal and vertical distribution of tropospheric ozone over the Atlantic Ocean in the southem and northern hemisphere, in Ozone in the Atmosphere, edited by R. D. Bjokov and P. Fabian, pp. 419-422, H. Deepack, Hampton, Va., 1989.

Smit, H.G.J., S. Gilge, and D. Kley, The meridional distribution of ozone and water vapor over the Atlantic Ocean between $30^{\circ} \mathrm{S}$ and $52^{\circ} \mathrm{N}$ in September/October 1988, in Physico-chemical Behavior of atmospheric Pollutants, edited by G. Restelli and G. Angeletti, pp. 630-637, Kluwer Acad., Norwell, Mass., 1990.

Strand, A., and $\emptyset$. Hov, A two-dimensional global study of the tropospheric ozone production, J. Geophys. Res., 99, 22,877-22,895, 1994.

Thompson, A. M., K. E. Pickering, R. R. Dickerson, W. G. Ellis, D. J. Jacob, J. R. Scala, W.-K. Tao, D. P. McNamara, and J. Simpson, Convective transport over the central United States and its role in regional CO and ozone budgets, J. Geophys. Res., 99, 18,703-18,711, 1994.

Winkler, P., Surface ozone over the Atlantic Ocean, J. Atmos. Chem., 7, 73-91, 1988.

Winkler, P., Meridional distribution of surface ozone over the Atlantic $\left(83^{\circ} \mathrm{N}-76^{\circ} \mathrm{S}\right)$, in Ozone in the atmosphere, edited by R.D. Bojkov and P. Fabian, pp. 423-424, A. Deepack, Norwell, Mass., 1989.

F. Flatøy and $\emptyset$. Hov, Geophysics Institute, University of Bergen, Allegaten 70, N-5007 Bergen, Norway. (e-mail: Frode.Flatoy@gfi.uib.no; Oystein.Hov@gfi.uib.no)

C. Gerbig, Institut für Chemie und Dynamik der Geosphăre (ICG-2), Forschungszentrum Jülich, D-52425 Jülich, Germany.

(e-mail: ch.gerbig@kfa-juelich.de)

S. J. Oltmans, NOAA Climate Monitoring and Diagnostics Laboratory, Boulder, CO 80303. (e-mail: soltmans@cmdl.noaa.gov)

(Received June 19, 1995; revised March 7, 1996; accepted March 28, 1996.) 